\title{
Diversified cropping systems support greater microbial cycling and retention of
}

carbon and nitrogen

Alison E. King ${ }^{1}$ and Kirsten S. Hofmockel ${ }^{1,2^{*}}$

${ }^{1}$ Department of Ecology, Evolution and Organismal Biology, Iowa State University, Ames, IA 50011, United States

${ }^{2}$ Pacific Northwest National Laboratory, Richland, WA, 99354 United States

*Corresponding author email: khof@iastate.edu

Keywords: Crop rotation; alternative agriculture; organic nitrogen; extracellular enzyme activity; microbial biomass; soil carbon

\section{Abstract}

18 Diversifying biologically simple cropping systems often entails altering other management

19 practices, such as tillage regime or nitrogen $(\mathrm{N})$ source. We hypothesized that the interaction of

20 crop rotation, $\mathrm{N}$ source, and tillage in diversified cropping systems would promote microbially-

21 mediated soil $\mathrm{C}$ and $\mathrm{N}$ cycling while attenuating inorganic $\mathrm{N}$ pools. We studied a cropping

22 systems trial in its $10^{\text {th }}$ year in Iowa, USA, which tested a 2-yr cropping system of corn (Zea

23 mays L.)/soybean [Glycine max (L.) Merr.] managed with conventional fertilizer N inputs and

24 conservation tillage, a 3-yr cropping system of corn/soybean/small grain + red clover (Trifolium

25 pratense L.), and a 4-yr cropping system of corn/soybean/small grain + alfalfa (Medicago sativa

26 L.)/alfalfa. Three year and 4-yr cropping systems were managed with composted manure,

27 reduced $\mathrm{N}$ fertilizer inputs, and periodic moldboard ploughing. We assayed soil microbial

28 biomass carbon (MBC) and $\mathrm{N}(\mathrm{MBN})$, soil extractable $\mathrm{NH}_{4}$ and $\mathrm{NO}_{3}$, gross proteolytic activity

29 of native soil, and potential activity of six hydrolytic enzymes eight times during the growing

30 season. At the $0-20 \mathrm{~cm}$ depth, native protease activity in the 4 -yr cropping system was greater 
31 than in the 2-yr cropping system by a factor of 7.9, whereas dissolved inorganic $\mathrm{N}$ pools did not

32 differ between cropping systems $(\mathrm{P}=0.292)$. At the $0-20 \mathrm{~cm}$ depth, $\mathrm{MBC}$ and $\mathrm{MBN}$ the $4-\mathrm{yr}$

33 cropping system exceeded those in the 2-yr cropping system by factors of 1.51 and 1.57 . Our

34 findings suggest that diversified crop cropping systems, even when periodically moldboard

35 ploughed, support higher levels of microbial biomass, greater production of bioavailable $\mathrm{N}$ from

36 SOM, and a deeper microbially active layer than less diverse cropping systems.

\section{1. Introduction}

The Midwestern United States ranks among the nation's most biologically altered landscapes

42 (Klopatek et al., 1979). It is dominated by annual grain crops fertilized with synthetic $\mathrm{N}$ and is

43 linked to multiple environmental costs, including soil erosion (Heathcote et al., 2013; Zaimes et

44 al., 2008), nutrient loss and attendant hypoxia (David et al., 2010; McIsaac et al., 2001), and

45 pesticide runoff (Davis et al., 2012; Gilliom et al., 2006). Incorporating hay, forage, or green

46 manures into cropping systems offers multiple benefits to the producer and to the environment

47 (Boody et al., 2005), including reduced reliance on synthetic fertilizers (Carlsson and Huss-

48 Danell, 2003; Davis et al., 2012), reduced nutrient losses (Randall et al., 1997; Vache et al.,

49 2002) and reduced soil erosion (Burkart et al., 2005; Vache et al., 2002). These legume or

50 manure-based systems also promote greater total and biologically active soil organic matter

51 (SOM) (Drinkwater et al., 1998; Kallenbach and Grandy, 2011; Maillard and Angers, 2014;

52 Poeplau and Don, 2015; Wander et al., 1994). SOM is important for crop N supply because soil 
53 organic $\mathrm{N}$ can provide $50 \%$ or more of crop $\mathrm{N}$ even when fertilizer $\mathrm{N}$ applications exceed crop

54 demand (Cassman et al., 2002).

55 Soil organic N is made up of about $40 \%$ proteinaceous material (Schulten and Schnitzer,

56 1998; Sowden et al., 1977), so the supply of plant-available N from SOM depends in large part

57 on protease enzymes that liberate amino acids (Jan et al., 2009; Schimel and Bennett, 2004)

58 which can be taken up directly by plants (Franklin et al., 2016) or readily mineralized to

59 ammonium (Jan et al., 2009). The extent to which amino acids contribute to plant available $\mathrm{N}$

60 depends on both the microbial production of protease enzymes and soil protein concentrations

61 (Hofmockel et al., 2010). Under native soil substrate conditions, amino acid production can

62 increase linearly with soil protein concentrations (Raab et al., 1999), suggesting that rates of

63 amino acid production are in some cases controlled by soil protein concentration. Therefore, the

64 liberation of bioavailable $\mathrm{N}$ is expected to be greater in soils with higher proteinaceous substrate

65 availability, such as legume- and manure-based cropping systems.

66 Understanding the microbial activities underlying coupled C-N cycling within integrated

67 management systems is necessary to project how interactions between crop rotation, $\mathrm{N}$ source,

68 and tillage regime affect soil $\mathrm{C}$ and $\mathrm{N}$ cycling at different soil depths. To test the effects of

69 management practices on soil $\mathrm{C}$ and $\mathrm{N}$ cycling and retention, researchers often isolate

70 management practices; for instance, the effects of inorganic compared to organic fertilizers

71 (Jenkinson and Rayner, 1977; Vitosh et al., 1996), non-use compared to use of green manure

72 (Baggs et al., 2000; Tonitto et al., 2006), or conservation tillage compared to conventional tillage

73 consisting of moldboard ploughing (Madejon et al., 2007; Melero et al., 2009). When

74 implementing cropping systems, however, producers often need to vary multiple factors at once

75 (Drinkwater, 2002). For instance, green manures and perennial forages frequently improve soil 
76 organic matter (Amado et al., 2006; McDaniel et al., 2014; Sanford et al., 2012), and often

77 require tillage (SARE, 2012), a management practice generally reported to reduce soil organic

78 matter (Alvarez et al., 1995; West and Post, 2002, although this effect depends on sampling

79 depth; see Luo et al., 2010).

80 Under conservation or zero tillage, crop residues accumulate in surface soils and increase

81 microbial activity and SOM in that layer relative to soils that are mixed with moldboard

82 ploughing (Alvear et al., 2005; Franzluebbers, 2002; Madejon et al., 2007). This increase has

83 been quantified as the stratification ratio, or the proportion of soil organic carbon (SOC) at the

84 soil surface relative to SOC in a deeper soil layer (Franzluebbers, 2002), and has been extended

85 to microbial biomass (Alvear et al., 2005; Madejon et al., 2007). Franzluebbers (2002) proposed

86 higher soil stratification ratios as unit-less, relative indicator of soil quality. Most researchers use

87 stratification ratios to compare cropping systems that are identical except for their tillage regime

88 and find that no-till or conservation tillage increases stratification ratios compared to

89 conventional tillage (Alvear et al., 2005; Madejon et al., 2007; Melero et al., 2009; Moreno et al.,

90 2006; Pu et al., 2015; Zhao et al., 2015). To our knowledge, no studies have reported on

91 stratification ratios under whole-systems comparisons in which both tillage and crop rotation

92 vary. Since cropping systems must often vary by both tillage regime and crop rotation, testing

93 stratification ratio in a whole-system comparison may be useful in determining its

94 generalizability as an indicator.

95 To test the effects of cropping system diversification - and associated changes in tillage

96 regime and $\mathrm{N}$ source - on microbial cycling of $\mathrm{C}$ and $\mathrm{N}$, we studied three corn-based cropping

97 systems (Table 1) within a long-term cropping systems experiment. These represent conventional

98 (2-yr) and diversified (3-yr and 4-yr) cropping systems in the Midwestern United States. We 
99 hypothesized that more diverse cropping systems would support 1) more microbial biomass and

100 higher rates of both native protease and potential enzyme activities, but 2) coincide with smaller

101 pools of dissolved inorganic nitrogen (DIN), and 3) display lower stratification ratios. In order to

102 hold the effect of crop on soil $\mathrm{C}$ and $\mathrm{N}$ cycling constant, we studied soils only under corn. This

103 whole-systems approach is not designed to isolate particular management practices as they

104 influence soil biological processes, but rather to study the impacts of integrated cropping systems

105 as they are likely to appear on farms.

106

107 2. Methods

108

109 2.1. Field Site

110

111 Field work was conducted at the Iowa State University Marsden Farm in Boone County,

112 Iowa ( $42^{\circ} 01^{\prime} \mathrm{N} ; 93^{\circ} 47^{\prime} \mathrm{W}$; $333 \mathrm{~m}$ above sea level) during the 2013 growing season (May -

113 October). Soils vary across the experimental site and are predominantly Clarion loam (fine-

114 loamy, mixed, superactive, mesic, Typic Hapludolls, 2\%-5\% slope), Nicollet loam (fine-loamy,

115 mixed, superactive, mesic, Aquic Hapludolls, 1-3\% slope) and Webster silty clay loam (fine-

116 loamy, mixed, superactive, mesic, Typic Endoaquolls, 0-2\% slope), with smaller areas of Harps

117 loam (fine-loamy, mixed, superactive, mesic Typic Calciaquolls, 0-2\% slope), and Canisteo silty

118 clay loam (fine-loamy, mixed, superactive, calcareous, mesic Typic Endoaquolls, 0-2\% slope).

119 Soil properties 0-20 cm are as follows: soil organic matter, $51 \mathrm{~g} \mathrm{~kg}^{-1}$, Bray P, $31 \mathrm{mg} \mathrm{kg}^{-1}$

120 (Liebman et al., 2008), and soil particle size distribution is 35\% sand, 38\% silt, and $26 \%$ clay.

121 Soil pH was 7.5 in May 2013. Weather conditions were measured about $1 \mathrm{~km}$ from the site: fifty 
122 year average annual rainfall from May to October at the site is $592 \mathrm{~mm}$ and mean temperature is

$12319^{\circ} \mathrm{C}$ for the same period. During 2013, total rainfall from May to October was slightly lower

124 than the long-term average, $436 \mathrm{~mm}$, and average air temperature was $19^{\circ} \mathrm{C}$. Prior to

125 establishment of experimental plots, the site had been managed for at least 20 years in corn-

126 soybean rotation receiving conventional fertilizer inputs.

\subsection{Cropping systems experiment}

131 randomized complete block design, with each crop phase of every crop rotation present every

132 year. Plots were 18 x $85 \mathrm{~m}$. The 2-yr cropping system was representative of conventional

133 cropping systems in the Midwestern US, and the 3-yr and 4-yr cropping systems were

134 representative of diversified farming systems in the Midwest. The small grain in both 3-yr and 4-

135 yr systems was triticale ( $\quad$ Triticosecale Wittmack) from 2003-2005 and oat (Avena sativa L.)

136 after 2006. In the 3-yr cropping system, red clover was used as a green manure (non-harvested),

137 and in the 4-yr cropping system, alfalfa was harvested for hay. All other crops were harvested for

138 grain and residues were left on the field. In all cropping systems, the late spring nitrate test

139 (Blackmer et al., 1997) was used for corn to determine rates for post-emergence side-dress $\mathrm{N}$

140 applications, so $\mathrm{N}$ applications varied by year (Table 1). All $\mathrm{N}$ was in form of $32 \%$ liquid urea

141 ammonium nitrate (UAN), urea, or monoammonium phosphate. Composted manure was applied

142 to 3-yr and 4-yr cropping systems in red clover and established alfalfa, respectively, at a rate of

$14310.2 \mathrm{Mg} \mathrm{ha}^{-1}$ (dry weight).

144 Working depth for moldboard plow used to incorporate red clover and alfalfa in the 
145 diversified cropping systems was $23 \mathrm{~cm}$, and working depth for chisel plow used for partial

146 incorporation of corn residue in all cropping systems was $33 \mathrm{~cm}$, however carbon measurements

147 from this site show that most corn residue was incorporated only to the 0-10 $\mathrm{cm}$ depth (Lazicki,

148 2011). More complete site descriptions, crop yields, and economic characteristics of cropping

149 systems are reported elsewhere (Davis et al., 2012; Liebman et al., 2008).

150

$151 \quad$ 2.2. Soil sampling

152

153 Soils were collected from the corn phase of each cropping system eight times throughout

154 the 2013 growing season (SI Table 1), an intensive sampling schedule designed to produce

155 accurate generalizations of system effects. At each sampling date, a set of 10 cores was taken

156 from each plot using a 2.2-cm diameter core, and soil cores were divided into 0-10 and 10-20 cm

157 depths before compositing. Sampling locations were randomized but were taken in a ratio of 3

158 row:1 inter-row to control for strong variability of root and N locations (e.g., Buczko et al.,

159 2008). Soils were sieved to $4 \mathrm{~mm}$ and stored at $4^{\circ} \mathrm{C}$ until subsampling (within 48 hours) for

160 subsequent analyses. Gravimetric moisture content was measured as water mass loss upon

161 drying at $105{ }^{\circ} \mathrm{C}$ to a constant weight and was used to determine wet-weight to dry-weight ratios.

162 Response variables are presented on a dry weight basis.

163

164 2.3. Microbial biomass and inorganic $N$

165

166 Microbial biomass was estimated using direct chloroform-fumigation-extraction

167 (modified from Vance et al., 1987 and Witt et al., 2000). Extracts were analyzed for non- 
168 purgeable organic $\mathrm{C}$ and total $\mathrm{N}$ via combustion catalytic oxidation (Shimadzu TOC-L analyzer,

169 Shimadzu Corporation, Columbia, Maryland, USA). Microbial biomass C and N were calculated

170 as the difference between fumigated and unfumigated extracts, with conversion factors of 0.45

171 for C (Vance et al., 1987) and 0.54 for $\mathrm{N}$ (Brookes et al., 1985). Unfumigated extracts were used

172 to measure $\mathrm{NO}_{3}$ and $\mathrm{NH}_{4}$ concentrations via spectrophotometry (BioTek Synergy HT plate

173 reader, BioTek Instruments, Inc., Winooski, VT, USA) (Hood-Nowotny et al., 2010).

174

175 2.4. Native protease activity

176

177 Proteolytic activity was measured with a method modified from Lipson et al. (1999) on

178 subsamples of soil stored at $-80^{\circ} \mathrm{C}$ (Brzostek et al., 2012). Soils were preincubated at $23^{\circ} \mathrm{C}$ for 12

179 hours. All soil samples ( 3.0-3.5 g) received $10 \mathrm{~mL} \mathrm{0.02} \mathrm{M} \mathrm{MOPS} \mathrm{buffer} \mathrm{at} \mathrm{pH}$ 7.5. All samples

180 also received $0.4 \mathrm{~mL}$ toluene, which inhibits microbial uptake (Skujins, 1967). Initial samples,

181 used to determine standing pool of free primary amines, received $3 \mathrm{~mL}$ trichloroacetic acid

182 (TCA) mix immediately in order to halt proteolytic reactions. Incubated samples were shaken

183 lengthwise at $120 \mathrm{rpm}$ for 4 hours at $23^{\circ} \mathrm{C}$ before addition of $3 \mathrm{~mL}$ TCA mix. All samples were

184 centrifuged at $2300 \mathrm{rpm}$ for $5 \mathrm{~min}$ and the supernatant filtered through Whatman \#42 papers.

185 Three technical replicates per plot and depth combination were run for both initial and incubated

186 samples, giving a total of 144 samples per sampling date. Extracts were stored at $-20^{\circ} \mathrm{C}$ until

187 analysis.

188 The concentration of total free primary amine-N (TFPA-N) in soil extracts was evaluated

189 using the o-phthaldialdehyde (OPA) and $\beta$-mercaptoethanol method, with an L-leucine standard

190 curve (Darrouzet-Nardi et al., 2013). Three analytical replicates per sample and incubation time 
191 combination were run on each plate, along with buffer blanks and an OPA standard curve. The

192 interference of $\mathrm{NH}_{4}$ with OPA reagent was subtracted using $\mathrm{NH}_{4}{ }^{+}$concentrations in MOPS

193 extracts determined via colorimetric analysis (Darrouzet-Nardi et al., 2013; Hood-Nowotny et al.,

194 2010). Native proteolytic rate ( $\eta \mathrm{mol}$ TPFA-N g soil ${ }^{-1} \mathrm{hr}^{-1}$ ) was calculated as the difference

195 between incubated and initial samples.

2.5. Potential enzyme activities

Potential enzyme activities were measured on subsamples of soil stored at $-20^{\circ} \mathrm{C}$. A suite

200 of six enzymes was measured, three involved in organic matter decomposition (BG, BX, and

201 CB) as well as three aminopeptidases (LAP, Ala, AAP), which liberate amino acids or

202 tripeptides from polypeptides. BG, BX and CB were tested with MUB (Methylumbelliferone) -

203 linked substrates: CB, 4-MUB- $\beta$-D-cellobioside; BG, 4-MUB $\beta$-D-glucopyranoside; BX, 4-

204 MUB $\beta$-D-xylosidase. Aminopeptidases were tested with MUC (7-amino-4-methylcoumarin) -

205 linked substrates: LAP, L-leucine-7-amido-4-MUC; Ala, L-alanine-7-amido-4-MUC; AAP, L-

206 alanine-alanine-phenylalanine-7-amido-4- MUC. Briefly, $1 \mathrm{~g}$ of soil was homogenized with 125

$207 \mathrm{~mL}$ of $100 \mathrm{mM}$ tris maleate buffer, $\mathrm{pH}$ 7.5. MUB- or MUC- linked substrates were added at

208 saturating concentrations of $400 \mu \mathrm{M}$ for all substrates. Plates were incubated at $23^{\circ} \mathrm{C}$ for 3 hours

209 and read using a fluorometer (360 nm excitation and $460 \mathrm{~nm}$ emission; BioTek Instruments, Inc.,

210 Winooski, VT, USA) without the addition of $\mathrm{NaOH}$. Eight analytical replicates per sample and

211 substrate combination were run and each plate included a MUB or MUC standard curve,

212 substrate controls, and homogenate controls. Enzyme activity was calculated as $\eta m o l$ enzyme $\mathrm{g}^{-}$

$213{ }^{1}$ soil $\mathrm{hr}^{-1}$ based on MUB or MUC standard curves and accounting for the quench of each sample 
214 (German et al., 2011). The linearity reaction of the 3-hour incubation was confirmed in

215 preliminary work.

216

217 2.6. Statistical analyses

218

219 We performed all analyses using repeated measures mixed effects ANOVA in JMP Pro

220 11. We averaged technical replicates from the same plot and depth before analysis, and we

221 calculated values for the whole soil profile $(0-20 \mathrm{~cm})$ by averaging values for samples of both

222 depths $(0-10$ and $10-20 \mathrm{~cm})$. We transformed data where necessary to meet assumptions of

223 normality. In the ANOVA mixed model, we used a full factorial of fixed effects for all response

224 variables except stratification ratios, with sampling date, depth, and cropping system as main

225 effects, as well as each of their interactions. Random terms included an 'ID' term, coded by plot

226 and depth (12 plots x 2 depths; total 24 'ID'), a plot term, and a block term. For stratification

227 ratios, we used an ANOVA mixed model with sampling date and cropping system as main

228 effects, their interaction, and block as a random effect. We used the residual covariance structure.

229 Subsequent pair-wise comparisons were made using Tukey's HSD. Significance was determined 230 at $\alpha=0.05$.

231

232 3. Results

233

234 3.1. Microbial biomass

235 
At the $0-20 \mathrm{~cm}$ depth, MBC in the 4-yr cropping system exceeded that in the 2-yr

237 cropping system by a factor of 1.51 and $(\mathrm{P}=0.023$, Fig. 1$)$, and $\mathrm{MBN}$ in the 4-yr cropping

238 system exceed that in the 2-yr cropping system by a factor of $1.57(\mathrm{P}=0.025) . \mathrm{MBC}$ and MBN

239 concentrations in the $0-20 \mathrm{~cm}$ depth of the 3 -yr year cropping system did not differ from either 2 -

240 yr or 4-yr cropping systems. MBC concentrations in the $0-10 \mathrm{~cm}$ depth did not differ between

241 any cropping systems, however the $10-20 \mathrm{~cm}$ depth in the 2-yr cropping system was lower than

242 the same depth of 3-yr or 4-yr cropping systems. MBN concentrations responded similarly to

243 depth and cropping system as did MBC concentrations (Fig. 2). The effect of cropping system on

$244 \mathrm{MBC}$ and $\mathrm{MBN}$ did not differ across sampling times $(\mathrm{P}=0.959)$.

246 3.2. Native protease and potential enzyme activities

249 proteolysis under the 2-yr cropping system by a factor of $8(\mathrm{P}=0.019$, Fig. 1$)$, with the 3-yr

250 cropping system intermediate. Within cropping systems, proteolytic rates were similar between

251 depths (Fig. 2). In the 0-20 cm depth, activities of BG and CB in the 3-yr cropping system

252 exceeded those in the 4-yr cropping system $(\mathrm{P}=0.045$ and $\mathrm{P}=0.047$, respectively, Fig. 1$)$, with

253 the 2-yr cropping system intermediate; activities of LAP and AAP exhibited a similar trend ( $\mathrm{P}=$

2540.102 and 0.076 , respectively, Fig. 1). Activities of BX and Ala did not differ significantly

255 between cropping systems when averaged over the $0-20 \mathrm{~cm}$ depth.

256 Most enzyme activities responded similarly to cropping system and depth, with some

257 variation in statistically significant differences (Fig. 2). In the 0-10 cm depth, all enzyme

258 activities were greatest in the 2-yr cropping system and least in the 4-yr rotation by factors 
259 ranging from 1.83 (BG) to 4.26 (AAP), with the 3-yr cropping system intermediate. In the 10-20

$260 \mathrm{~cm}$ depth, enzyme activities in the 3-yr and 4-yr cropping systems were similar to or greater than

261 those in the 2-yr cropping system. The effect of cropping system on native proteolyic and

262 potential enzyme activities did not differ over the growing season.

264 3.4. Specific enzyme activity

Potential enzyme activity was normalized by MBC to determine biomass-specific activity.

267 For all enzymes in the $0-20 \mathrm{~cm}$ depth, the 3 -yr cropping system trended toward higher specific

268 activity than the 4-yr cropping system, although this relationship was significant only for CB (P

$269=0.029$, Fig. 3). Similarly, for all enzymes the 2-yr rotation trended toward higher specific

270 activity than the 4-yr cropping system, although this relationship was significant only for $\mathrm{CB}(\mathrm{P}=$

271 0.046). Specific activities of the 2-yr and 3-yr cropping systems were not statistically different

272 for any enzyme.

273 For all enzymes, potential activities in the $0-10 \mathrm{~cm}$ depth were highest in the 2-yr

274 cropping system and lowest in the 4-yr cropping system by factors ranging from 2.20 (BG) to

2755.50 (CB), with the 3-yr cropping system intermediate (Fig. 4). In the 10-20 cm depth, specific

276 enzyme activities in the 3-yr and 4-yr cropping systems were similar to or greater than those in

277 the 2-yr rotation.

278

279 3.5. Stratification ratios of $M B C$ and $M B N$

280 
Stratification ratios of MBC and MBN were greater in the 2-yr cropping system than

282 either the 3-yr or 4-yr cropping system ( $\mathrm{P}<0.0001$ for all comparisons, Fig. 5); stratification

283 ratios in the 2-yr cropping system exceeded one whereas stratification ratios in the 3-yr and 4-yr

284 cropping systems were close to but less than one. Stratification ratios did not differ between 3-yr

285 and 4-yr cropping systems for either MBC or MBN $(\mathrm{P}>0.17)$.

\subsection{Inorganic nitrogen}

Temporal dynamics of DIN were similar across depths and cropping systems (Fig 6).

290 Nitrogen concentrations were low at both depths early in the season, in May and June. After side

291 dress $\mathrm{N}$, on 23 July, the $0-10 \mathrm{~cm}$ depth showed a more marked increase in DIN concentrations

292 than did the $10-20 \mathrm{~cm}$ depth. Across all cropping systems, DIN concentrations in the $0-10 \mathrm{~cm}$

293 depth were greater than those in the $10-20 \mathrm{~cm}$ depth, and ammonium showed a similar trend $(\mathrm{P}=$

294 0.062, Table 3). Ammonium was the only $\mathrm{N}$ form to differ significantly by cropping system,

295 irrespective of depth (Table 3). Ammonium concentrations in the 4-yr cropping system were

$29638 \%$ lower than in the 2-yr cropping system $(\mathrm{P}=0.042)$, with the 3 -yr cropping system

297 intermediate. There was no significant time by cropping system interaction for ammonium, 298 nitrate or DIN.

300 4. Discussion

301

Our analysis of microbially mediated $\mathrm{C}$ and $\mathrm{N}$ cycling at a 10-year cropping systems

303 experiment showed diversified cropping systems support higher rates of soil organic matter 
304 depolymerization and greater retention of $\mathrm{C}$ and $\mathrm{N}$ in microbial biomass. Our results support the

305 notion that through their metabolic activity and biomass dynamics, it is soil microbes' response

306 to cropping system diversification that plays a key role in improving soil quality (Bach and

307 Hofmockel, 2015; Kallenbach et al., 2015). The 3-yr and 4-yr cropping systems compared to the

308 2-yr cropping system supported higher levels of MBC and MBN. Although increases in soil C

309 pools are often attributed to increases in C inputs (Kong et al., 2005; Rasmussen et al., 1980), at

310 Marsden Farm levels of $\mathrm{C}$ inputs did not predict those of microbial biomass $\mathrm{C}$. The 4-yr cropping

311 system provided the least C input annualized over the full rotation period (Table 2, Lazicki et al.,

312 2016). Despite lower C inputs, the 4-yr cropping system supports enhanced microbial biomass

313 compared to other cropping systems, as discussed below.

314 Cropping system management can alter microbial physiology to increase microbial

315 carbon use efficiency (CUE), that is, the efficacy with which microorganisms convert available

316 organic substrates into microbial biomass (Kallenbach et al., 2015). The microbial biomass C

317 and $\mathrm{N}$ pools will increase in one cropping system relative to another only if microbes have access

318 to sufficient substrates and non-growth requirements have been satisfied. Therefore, greater

319 microbial biomass in diversified cropping systems may be a consequence of increased substrate

320 availability, where greater retention and recycling of $\mathrm{C}$ and $\mathrm{N}$ enhance available substrate to

321 support microbial growth and biosynthesis (Geyer et al., 2016). This is supported by greater

322 pools of decomposable substrate in diversified systems at Marsden Farm. Despite lower C inputs,

323 the diversified systems at Marsden Farm accumulate particulate organic C (Lazicki, 2011),

324 which correlates positively with both microbial biomass and extracellular enzyme activity

325 (Fernandes et al., 2011). Greater substrate availability in the diversified cropping systems is

326 evidenced by higher rates of native proteolytic enzyme activity, where the 4-yr cropping system 
327 increased native protease activity by 8 fold compared to the 2 -yr cropping system. Diversified

328 cropping systems support this increase in proteolytic rates despite receiving similar levels of total

329 N input (including biological nitrogen fixation, Lazicki et al., 2016). Because these are native

330 rates (no substrate additions), rates of amino acid liberation most closely reflect differences in

331 bioavailable $\mathrm{N}$ and $\mathrm{C}$ between cropping systems. Together, greater proteolytic activity coupled

332 with greater microbial biomass $\mathrm{C}$ and $\mathrm{N}$ suggest enhanced cycling and retention of $\mathrm{C}$ and $\mathrm{N}$ in

333 the diversified systems.

334 In response to cropping systems intensified with inorganic $\mathrm{N}$ fertilizer, such as the 2-yr

335 cropping system, microbial communities can also increase biomass-specific enzyme activity,

336 producing more enzymes per unit of microbial biomass (Lagomarsino et al., 2009). In the 2-year

337 cropping system, biomass-specific enzyme activity was greatest in the $0-10 \mathrm{~cm}$ increment, which

338 may reflect $\mathrm{N}$ fertilizer applications. In the $10-20 \mathrm{~cm}$ soil increment of the 2 -yr cropping system,

339 very low specific rates likely reflect low overall investment in enzymes; here resources were

340 primarily allocated to microbial maintenance and survival, as evidenced by significantly lower

341 microbial biomass. These dynamics contrast the 3-yr and 4-yr cropping systems, where specific

342 rates of enzyme activity do not differ with depth and tend to be lowest in the 4-year cropping

343 system where particulate organic C (Lazicki, 2011) and microbial biomass are greatest.

344 Microbial biomass may also be suppressed by higher rates of $\mathrm{N}$ fertilizer in the 2-yr

345 cropping system relative to 3-yr and 4-yr cropping systems. $\mathrm{N}$ fertilizer can reduce soil $\mathrm{pH}$,

346 which is positively correlated with microbial biomass (Serna-Chavez et al., 2013). Previous

347 studies demonstrate that microbial biomass may be depressed by inorganic $\mathrm{N}$ inputs (Liebig et al.,

348 2002; Treseder, 2008), potentially offsetting the effect of greater C inputs and contributing to

349 lower MBC in the 2-yr cropping system. 
351 as microbial resource allocation toward enzyme production diverts resources from microbial

352 growth and reproduction (Hargreaves and Hofmockel, 2013; Schimel and Schaeffer, 2012).

353 Microbial growth is positively correlated with SOM accrual (Bradford et al., 2013), and much of

354 SOM is thought to be comprised of microbial residues (Schmidt et al., 2011; Simpson et al.,

355 2007). While SOM in the $0-20 \mathrm{~cm}$ does not differ at this site (Lazicki et al., 2016), changes in

356 microbial community physiology can explain why the 4-yr rotation is able to maintain similar

357 total C stocks as the 2-yr cropping system despite receiving on average only three quarters the $\mathrm{C}$

358 input. This is not mutually exclusive with other factors influencing $\mathrm{C}$ retention that were not

359 measured in our study, such as soil temperature (Frey et al., 2013), bulk density (Wang et al.,

360 2015), or C input quality (Cotrufo et al., 2013). Specifically, the lower C:N and lignin:N ratios of

361 alfalfa biomass compared to corn and soybean (Johnson et al., 2007) may also be implicated in

362 promoting carbon retention in the 4-yr cropping system. Overall our findings suggest that

363 cropping systems with less frequent tillage, reduced fertilizer $\mathrm{N}$ inputs, and/or those diversified

364 with perennial forages can decrease the specific enzyme activity of microbial communities and

365 promote microbial biomass $\mathrm{C}$ and $\mathrm{N}$, which in turn enhances the potential for SOM accumulation.

366 In addition to promoting greater proteolytic activity and microbial biomass, the

367 microbially active layer extended deeper in the soil profile in the diversified cropping systems. In

368 the $10-20 \mathrm{~cm}$ increment, microbial biomass $\mathrm{C}$ and $\mathrm{N}$ and native proteolysis were substantially

369 enhanced in the diversified systems. These depth dynamics were similar for potential rates of

370 hydrolytic enzymes, which measure enzyme pools given unlimited substrate. In the 3- and 4-yr

371 cropping systems, enzyme production did not differ with depth, whereas the 2-year cropping

372 system harbored significantly smaller enzyme pools in the $10-20 \mathrm{~cm}$ compared to the $0-10 \mathrm{~cm}$ 
373 increment, suggesting a reduced zone of microbial activity. This stratification under the 2-yr

374 cropping system, which received conservation tillage, is consistent with enzyme stratification

375 under conservation tillage or zero tillage at other sites (Alvear et al., 2005; Madejon et al., 2007).

376 Stratification ratios of SOM, and SOM pools themselves, generally respond in the same

377 direction to conservation or no-tillage compared to moldboard ploughing. That is, total SOM in

378 the plough layer of moldboard ploughed systems is usually similar to that under conservation

379 tillage, or somewhat decreased (Alvear et al., 2005; Hermle et al., 2008; Moreno et al., 2006). In

380 most tillage comparisons, however, only annual grain crops are investigated and all aspects of

381 cropping systems are held constant except tillage regimes (Alvear et al., 2005; Moreno et al.,

382 2006; West and Post, 2002; Zhao et al., 2015), eliminating the possibility that crop

383 diversification with small grains, green manures, or perennial forages could interact with tillage

384 to influence both stratification ratios and total SOM pools. We found that the interaction between

385 crop rotation and tillage can enhance soil quality in agroecosystems. At the Marsden Farm,

386 conservation tillage (2-yr rotation) increased stratification ratios of $\mathrm{MBC}$ and $\mathrm{MBN}$ relative to

387 moldboard ploughing (3-yr and 4-yr rotations), despite supporting significantly lower MBC and

388 MBN throughout the plough layer.

389 Differences in crop species among cropping systems may have accentuated stratification

390 dynamics promoted by tillage regimes: a crop with high shoot:root ratio like corn (Bolinder et al.,

391 2007) may accentuate depth stratification, whereas lower shoot:root ratios of alfalfa and red

392 clover (Bolinder et al., 2007; Hogh-Jensen and Schoerring, 2001) may support a less stratified

393 layer of microbial abundance irrespective of tillage regime. Our study suggests that stratification

394 ratio is most appropriate as an indicator of soil mixing via tillage, but not necessarily an indicator

395 of overall soil health, as perennial forages and green manures can remediate soil microbial 
396 biomass even under moldboard ploughing. This work highlights the importance of whole

397 systems approaches for accurately assess cropping system impacts on soil quality.

398 In the season under study, 3-yr and 4-yr cropping systems did not significantly reduce

399 inorganic $\mathrm{N}$ pools compared to 2-yr crop rotations (Table 3). These findings contrast those of

400 Tomer and Liebman (2014), who assessed $\mathrm{NO}_{3}-\mathrm{N}$ concentrations at Marsden Farm at $1.2 \mathrm{~m}$ and

401 found that across the 2004-2011 growing seasons, spring $\mathrm{NO}_{3}-\mathrm{N}$ concentrations in the corn phase

402 of the 4-yr rotation were $37 \%$ and $24 \%$ of 3-yr and 2-yr rotations, respectively. The lack of

403 cropping system effect on DIN pools in our results may be due to the heterogeneity of DIN pools

404 in the environment (Cambardella et al., 1994), seasonal variations in both DIN production from

405 SOM (Zak et al., 1999) and transport via leaching (David et al., 2010), or the inter-annual

406 variability in fertilizer $\mathrm{N}$ application rates at Marsden Farm (Table 1). Historically, corn in the 2-

407 yr cropping system received about four times the fertilizer $\mathrm{N}$ of corn in 3-yr and 4-yr cropping

408 systems, but in the season under study here, the 2-yr cropping system received only about three

409 times the fertilizer $\mathrm{N}$ of the 3-yr and 4-yr cropping systems.

410 The similarities in corn season DIN concentrations between cropping systems, and thus

411 comparable vulnerability of $\mathrm{N}$ to loss via leaching, suggest that long-term $\mathrm{N}$ retention

412 demonstrated elsewhere in cropping systems diversified with green manures or perennials is the

413 result of greater time of living soil cover than under cropping systems of only annual grains

414 (Drinkwater et al., 1998; Randall et al., 1997; Syswerda et al., 2012). Nevertheless, that 3-yr and

415 4-yr cropping systems maintained DIN pools of comparable size to the 2-yr cropping system

416 despite receiving less $\mathrm{N}$ fertilizer during the study season suggests that production of $\mathrm{N}$ from

417 SOM (e.g., via proteolysis and then mineralization), rather than $\mathrm{N}$ fertilizer, maintained a greater

418 proportion of the DIN pools in these cropping systems compared to the 2-yr cropping system. 
419 Indeed, at Marsden Farm, the diversified cropping systems on average support 27\% greater gross

$420 \mathrm{~N}$ mineralization than the 2-yr cropping system, and all cropping systems support similar levels

421 of corn $\mathrm{N}$ uptake (Osterholz et al., 2016). These results suggest diversified cropping systems

422 have the potential for reduced reliance on fertilizer $\mathrm{N}$ inputs and the potential for tighter coupling

423 of DIN supply and plant demand.

424

425 5. Conclusions

426

427

We found that cropping systems diversification increases $\mathrm{MBC}, \mathrm{MBN}$, and native

428 protease activity throughout the plough layer relative to less diverse systems. The increased

429 retention of organic inputs in microbial biomass in diverse rotations coincided with greater return

430 on enzymatic investment, suggesting microbial efficiency may be promoted by moldboard

431 plough incorporation of a green manure or perennial legume. Increases in SOM

432 depolymerization with diversification are consistent with retention of residue inputs in microbial

433 biomass N (Geisseler and Horwath, 2008) and suggest that depolymerization was primarily

434 limited by soil protein concentration (Raab et al., 1999). Our findings highlight that in contrast to

435 systems relying on inorganic $\mathrm{N}$ inputs, diversified cropping systems receiving organic

436 amendments can promote $\mathrm{C}$ and $\mathrm{N}$ retention. Understanding the microbial ecology of cropping

437 systems is important for predicting their effects on C cycling; substituting small grains or alfalfa

438 hay for cereal grains often decreases C inputs (Bell et al., 2012; Benjamin et al., 2010; Gregorich

439 et al., 2001), but may nonetheless enhance soil quality. The whole-systems approach to site

440 design studied here provides an important comparison of tillage regimes contextualized within

441 cropping systems. When crops are held constant, tillage is generally reported to reduce microbial 
442 biomass (Pandey et al., 2014), and deep tillage like moldboard plowing is discouraged for the

443 sake of conserving soil organic matter stocks (Karlen et al., 2013). Our results suggest that cover

444 crops and perennial forages may remediate soil microbial biomass beyond the detrimental effects

445 of the tillage they often require.

446

\section{Acknowledgements}

449 This work was supported by USDA National Institute of Food \& Agriculture grant number 2014-

450 67019-21628. We thank Don Zak and Matt Liebman for helpful feedback on the manuscript.

451 We thank Queenster Nartey, Sandra Greenwood, Jessica Maciel-Hernandez, and Montana Smith

452 for their assistance in the lab. We are grateful to the late Dave Sundberg for his maintenance of 453 the Marsden farm field plots. 
Table 1. Cropping system management at Marsden Farm: cropping system, tillage regime, and nitrogen inputs (excluding biological nitrogen fixation). Nitrogen inputs for year of study (2013) listed separately. Numbers in parentheses represent standard deviation of fertilizer inputs.

\begin{tabular}{|c|c|c|c|c|c|c|c|}
\hline \multirow{4}{*}{ Cropping System } & & & & \\
\hline & \multirow{2}{*}{\multicolumn{2}{|c|}{ Tillage regime }} & \multirow{3}{*}{$\begin{array}{l}\text { Fertilizer } \\
\text { preplant }+ \\
\text { sidedress }\end{array}$} & \multirow[t]{3}{*}{ Manure $^{\mp}$} & \multicolumn{2}{|c|}{ Fertilizer } & \multirow[t]{3}{*}{ Manure } \\
\hline & & & & & preplant & sidedress $^{b}$ & \\
\hline & Spring (prior to planting) & Fall (after harvest) & & & \multicolumn{2}{|c|}{$\mathrm{Nha}^{-1}$} & \\
\hline \multicolumn{8}{|l|}{$2-y r$} \\
\hline corn & - & chisel plow & $154(40)$ & - & 112 & 112 & - \\
\hline soybean & field cultivation & - & $5(8)$ & - & - & & - \\
\hline \multicolumn{8}{|l|}{$3-y r$} \\
\hline corn & disking \& field cultivation & chisel plow & $45(50)$ & $116(38)$ & - & 84 & 95 \\
\hline soybean & field cultivation & - & $4(7)$ & - & - & & \\
\hline small grain + red clover & zero tillage or disking & moldboard plow & $26(5)$ & - & - & & - \\
\hline \multicolumn{8}{|l|}{$4-y r$} \\
\hline corn & disking \& field cultivation & chisel plow & $34(38)$ & $116(38)$ & - & 56 & 95 \\
\hline soybean & field cultivation & - & - & - & - & & - \\
\hline small grain + alfalfa & zero tillage or disking & - & $26(5)$ & - & - & & - \\
\hline alfalfa & - & moldboard plow & $18\left(^{*}\right)$ & - & - & & - \\
\hline \multicolumn{8}{|c|}{$\begin{array}{l}\text { *only one fertilizer } \mathrm{N} \text { application, } 2006 \\
{ }^{\mp} \text { Total } \mathrm{N} \text {, not available } \mathrm{N} \text {; manure is applied in the fall } \\
\text { preceding corn }\end{array}$} \\
\hline \multicolumn{8}{|c|}{ a - preplant N fertilizer applied on 15 May 2015} \\
\hline - sidedress $N$ fertilizer appli & on 28 June 2013 & & & & & & \\
\hline
\end{tabular}


Table 2. Carbon inputs to the corn phase and annualized over all crop phases, and SOC stocks by cropping system. Carbon inputs represent the sum of aboveground crop residue, standing summer root biomass, root exudates (estimated as 65\% of root biomass, (Bolinder et al., 2007), and manure C inputs in 2008-2009). Standard deviations in parentheses. All values from Lazicki et al., (2016).

\begin{tabular}{|c|c|c|c|c|c|c|c|c|c|c|c|c|c|c|c|c|c|c|}
\hline \multirow[t]{2}{*}{ Phase } & \multirow[t]{2}{*}{$\begin{array}{l}\text { Cropping } \\
\text { system }\end{array}$} & \multicolumn{3}{|c|}{$\begin{array}{c}\text { Aboveground } \\
\text { biomass }\end{array}$} & \multicolumn{5}{|c|}{$\begin{array}{l}\text { Est. root } \\
\text { exudates }\end{array}$} & & anure & & \multicolumn{3}{|c|}{ Total C inputs } & \multicolumn{3}{|c|}{ SOC } \\
\hline & & \multicolumn{14}{|c|}{$g C m^{-2} y r^{-1}$} & \multicolumn{3}{|c|}{$M g h a^{-1}$} \\
\hline \multirow[t]{3}{*}{ Corn } & $2-y r$ & 374.6 & $(38.8)$ & $a^{a}$ & 14.7 & (3.5) & $\mathrm{a}$ & 14.72 & $(3.7)$ & & & & 404.5 & $(40.3)$ & $b$ & & & \\
\hline & $3-y r$ & 428 & $(50.2)$ & $\mathrm{a}$ & 12.43 & (3.0) & $\mathrm{a}$ & 13.24 & (3.1) & 138.2 & $(0.0)$ & & 592.8 & (48.9) & $\mathrm{a}$ & & & \\
\hline & $4-y r$ & 413.5 & $(51.8)$ & $a$ & 12.78 & $(4.7)$ & $\mathrm{a}$ & 12.00 & $(6.7)$ & 138.2 & $(0.0)$ & & 577.6 & $(57.6)$ & $\mathrm{a}$ & & & \\
\hline \multicolumn{19}{|c|}{$\begin{array}{l}\text { Average of } \\
\text { all crop }\end{array}$} \\
\hline \multirow[t]{3}{*}{ years } & $2-y r$ & 293.1 & (93.1) & $\mathrm{a}$ & 13.15 & (3.4) & $\mathrm{a}$ & 12.56 & $(4.1)$ & & & & 319.2 & $(97.2)$ & $\mathrm{a}$ & 58.98 & $(6.64)$ & $\mathrm{a}$ \\
\hline & $3-y r$ & 304.9 & (97.9) & $\mathrm{a}$ & 11.18 & $(2.6)$ & $\mathrm{a}$ & 9.96 & (3.3) & 46.1 & $(68.0)$ & $\mathrm{a}$ & 372.6 & (166.6) & $\mathrm{a}$ & 56.05 & (7.72) & $\mathrm{a}$ \\
\hline & $4-y r$ & 175.8 & (178.6) & a & 12.56 & (6.8) & $a$ & 11.89 & $(4.5)$ & 34.6 & (61.8) & $\mathrm{b}$ & 235.6 & (231.2) & $\mathrm{b}$ & 58.4 & (7.69) & $\mathrm{a}$ \\
\hline
\end{tabular}

a - Different lowercase letters represent differences between systems in a specified crop that were significant at P = 0.05 (Tukey's HSD) 
Table 3. Mean inorganic $\mathrm{N}$ concentration by crop system and depth, averaged across sampling dates.

\begin{tabular}{|c|c|c|c|c|c|}
\hline \multirow{3}{*}{$\begin{array}{c}\text { Crop } \\
\text { System } \\
\text { 2-yr }\end{array}$} & \multirow{3}{*}{$\begin{array}{l}\text { Depth } \\
0-10 \mathrm{~cm} \\
10-20 \mathrm{~cm}\end{array}$} & $\mathrm{NO}_{3}{ }^{-} \mathrm{N}$ & $\begin{array}{c}\mathbf{N H}_{4}{ }^{+}-\mathbf{N} \\
u g g^{-1} \text { soil }\end{array}$ & \multicolumn{2}{|c|}{ Total DIN } \\
\hline & & $27.89 \quad \mathrm{a}^{\mathrm{a}}$ & $9.93 \quad \mathrm{a}$ & 42.53 & $a$ \\
\hline & & $11.32 \mathrm{~b}$ & $4.48 \mathrm{ab}$ & 18.74 & $b$ \\
\hline \multirow[t]{2}{*}{$3-y r$} & $0-10 \mathrm{~cm}$ & $16.17 \mathrm{ab}$ & $6 a b$ & 24.23 & $a b$ \\
\hline & $10-20 \mathrm{~cm}$ & $14.45 \mathrm{~b}$ & $5.23 \mathrm{ab}$ & 22.58 & $b$ \\
\hline \multirow[t]{2}{*}{$4-y r$} & $0-10 \mathrm{~cm}$ & $19.85 \mathrm{ab}$ & $5.46 \mathrm{ab}$ & 28.74 & $a b$ \\
\hline & $10-20 \mathrm{~cm}$ & $14.55 \mathrm{~b}$ & $3.25 \mathrm{~b}$ & 20.85 & $b$ \\
\hline $2-y r$ & $0-20 \mathrm{~cm}$ & $18.23 \mathrm{~A}^{\mathrm{b}}$ & $6.79 \mathrm{~A}$ & 28.23 & A \\
\hline $3-y r$ & & $15.3 \mathrm{~A}$ & $5.6 \quad A B$ & 23.39 & A \\
\hline $4-y r$ & & $17.05 \mathrm{~A}$ & $4.24 \quad B$ & 24.48 & A \\
\hline SE & & 1.13 & 1.71 & 2.59 & \\
\hline
\end{tabular}

a - Entries in a column that share a lowercase letter are not significantly different at $P=0.05$ (Tukey's HSD)

$b$ - Entries in a column that share an uppercase letter are not significantly different at $P=0.05$ (Tukey's HSD)

\section{Figure legends}

Fig 1. Mean soil indicators cropping systems at $0-20 \mathrm{~cm}$ depth averaged across eight sampling dates in 2013. Error bars represent standard errors $(n=32: 4$ plots $x 8$ sampling dates). Bars within a frame that share a letter are not significantly different at $\mathrm{P}=0.05$ (Tukey's HSD). A) Native protease activity, or production of total free primary amine-N (TFPA-N). B) Soil microbial biomass carbon and nitrogen. C) Potential enzyme activities.

Fig 2. Mean soil indicators for cropping systems at 0-10 and 10-20 cm depths, averaged across eight sampling dates in 2013. Error bars represent standard errors $(n=32: 4$ plots $\mathrm{x} 8$ sampling dates). Bars within a frame that share a letter are not significantly different at $\mathrm{P}=0.05$ (Tukey's HSD). A) Native protease activity, or production of total free primary amine-N (TFPA-N). B) Soil microbial biomass carbon and nitrogen. C) Potential enzyme activities.

Fig 3. Mean specific enzyme activity for cropping systems at $0-20 \mathrm{~cm}$ depth, averaged across eight sampling dates in 2013. Error bars represent standard errors $(n=32: 4$ plots 
x 8 sampling dates). Bars within a frame that share a letter are not significantly different at $\mathrm{P}=0.05$ (Tukey's HSD).

Fig 4. Mean specific enzyme activity for cropping systems at 0-10 and 10-20 cm depths, averaged across eight sampling dates in 2013. Error bars represent standard errors $(\mathrm{n}=$ 32: 4 plots $\mathrm{x} 8$ sampling dates). Bars within a frame that share a letter are not significantly different at $\mathrm{P}=0.05$ (Tukey's HSD).

Fig 5. Stratification ratios $(0-10 \mathrm{~cm} / 10-20 \mathrm{~cm})$ of $M B C$ and $M B N$.

Fig 6. Concentrations of dissolved inorganic nitrogen (DIN) between cropping systems and depths across the 2013 corn growing season.

\section{References}

Alvarez, R., Diaz, R.A., Barbero, N., Santanatoglia, O.J., Blotta, L., 1995. Soil organic carbon, microbial biomass, and $\mathrm{CO} 2-\mathrm{C}$ production from three tillage systems. Soil Tillage Res. 33, 17-28.

Alvear, M., Rosas, A., Rouanet, J.L., Borie, F., 2005. Effects of three soil tillage systems on some biological activities in an Ultisol from southern Chile. Soil Tillage Res. 82, 195-202.

Amado, T.J.C., Bayer, C., Conceição, P.C., Spagnollo, E., de Campos, B.-H.C., da Veiga, M., 2006. Potential of Carbon Accumulation in No-Till Soils with Intensive Use and Cover Crops in Southern Brazil. J. Environ. Qual. 35, 1599-1607.

Bach, E.M., Hofmockel, K.S., 2015. Coupled Carbon and Nitrogen Inputs Increase Microbial Biomass and Activity in Prairie Bioenergy Systems. Ecosystems 1, 417427. doi:10.1007/s10021-014-9835-8

Baggs, E.M., Watson, C.A., Rees, R.M., 2000. The fate of nitrogen from incorporated cover crop and green manure residues. Nutr. Cycl. Agroecosystems 56, 153-163.

Bell, L.W., Sparling, B., Tenuta, M., Entz, M.H., 2012. Soil profile carbon and nutrient stocks under long-term conventional and organic crop and alfalfa-crop rotations and re-established grassland. Agric. Ecosyst. Environ. 158, 156-163.

Benjamin, J.G., Halvorson, A.D., Nielsen, D.C., Mikha, M.M., 2010. Crop Management Effects on Crop Residue Production and Changes in Soil Organic Carbon in the Central Great Plains. Agron. J. 102, 990.

Blackmer, A.M., Voss, R.D., Mallarino, A.P., 1997. Nitrogen Fertilizer Recommendations for Corn in Iowa. Iowa State Univ. Ext. 1-4.

Bolinder, M.A., Janzen, H.H., Gregorich, E.G., Angers, D.A., VandenBygaart, A.J., 2007. An approach for estimating net primary productivity and annual carbon inputs to soil for common agricultural crops in Canada. Agric. Ecosyst. Environ. 118, 29-42.

Boody, G., Vondracek, B., Andow, D.A., Krinke, M., Westra, J., Zimmerman, J., Welle, P., 2005. Multifunctional agriculture in the United States. Bioscience 55, 27-38.

Bradford, M.A., Keiser, A.D., Davies, C.A., Mersmann, C.A., Strickland, M.S., 2013. 
Empirical evidence that soil carbon formation from plant inputs is positively related to microbial growth. Biogeochemistry 113, 271-281.

Brookes, P.C., Landman, A., Pruden, G., Jenkinson, D.S., 1985. Chloroform fumigation and the release of soil nitrogen: a rapid direct extraction method to measure microbial biomass nitrogen in soil. Soil Biol. Biochem. 17, 837-842.

Brzostek, E.R., Greco, A., Drake, J.E., Finzi, A.C., 2012. Root carbon inputs to the rhizosphere stimulate extracellular enzyme activity and increase nitrogen availability in temperate forest soils. Biogeochemistry 115, 65-76.

Buczko, U., Kuchenbuch, R.O., Gerke, H.H., 2008. Evaluation of a core sampling scheme to characterize root length density of maize. Plant Soil 316, 205-215.

Burkart, M., James, D., Liebman, M., Herndel, C., 2005. Impacts of integrated croplivestock systems on nitrogen dynamics and soil erosion in western Iowa watersheds. J. Geophys. Res. 110, G01009.

Cambardella, C.A., Moorman, T.B., Novak, J.M., Parkin, T.B., Karlen, D.L., Turco, R.F., Konopka, A.E., 1994. Field-scale variability of soil properties in Central Iowa soils. Soil Sci. Soc. Am. J. 58, 1501-1511.

Carlsson, G., Huss-Danell, K., 2003. Nitrogen fixation in perennial forage legumes in the field. Plant Soil 253, 353-372.

Cassman, K.G., Dobermann, A., Walters, D.T., 2002. Agroecosystems, nitrogen-use efficiency, and nitrogen management. Ambio 31, 132-140.

Cotrufo, M.F., Wallenstein, M.D., Boot, C.M., Denef, K., Paul, E., 2013. The Microbial Efficiency-Matrix Stabilization (MEMS) framework integrates plant litter decomposition with soil organic matter stabilization: do labile plant inputs form stable soil organic matter? Glob. Chang. Biol. 19, 988-995.

Darrouzet-Nardi, A., Ladd, M.P., Weintraub, M.N., 2013. Fluorescent microplate analysis of amino acids and other primary amines in soils. Appl. Soil Ecol. 57, 7882.

David, M.B., Drinkwater, L.E., McIsaac, G.F., 2010. Sources of Nitrate Yields in the Mississippi River Basin. J. Environ. Qual. 39, 1657.

Davis, A.S., Hill, J.D., Chase, C.A., Johanns, A.M., Liebman, M., 2012. Increasing Cropping System Diversity Balances Productivity, Profitability and Environmental Health. PLoS One 7, e47149.

Drinkwater, L.E., 2002. Cropping Systems Research: Reconsidering Agricultural Experimental Approaches. HorTechnology 12, 355-361.

Drinkwater, L.E., Wagoner, P., Sarrantonio, M., 1998. Legume-based cropping systems have reduced carbon and nitrogen losses. Nature 396, 262-265.

Fernandes, M.F., Barreto, A.C., Mendes, I.C., Dick, R.P., 2011. Short-term response of physical and chemical aspects of soil quality of a kaolinitic Kandiudalfs to agricultural practices and its association with microbiological variables. Agric.

Ecosyst. Environ. 142, 419-427. doi:10.1016/j.agee.2011.07.002

Franklin, O., Cambui, C.A., Gruffman, L., Palmroth, S., Oren, R., Näsholm, T., 2016. The carbon bonus of organic nitrogen enhances nitrogen use efficiency of plants. Plant, Cell Environ. 1-11. doi:10.1111/pce.12772

Franzluebbers, A.J., 2002. Soil organic matter stratification ratio as an indicator of soil quality. Soil Tillage Res. 66, 95-106.

Frey, S.D., Lee, J., Melillo, J.M., Six, J., 2013. The temperature response of soil 
microbial efficiency and its feedback to climate. Nat. Publ. Gr. 3, 1-4.

Geisseler, D., Horwath, W.R., 2008. Regulation of extracellular protease activity in soil in response to different sources and concentrations of nitrogen and carbon. Appl. Soil Ecol. 40, 3040-3048.

German, D.P., Weintraub, M.N., Grandy, A.S., Lauber, C.L., Rinkes, Z.L., Allison, S.D., 2011. Optimization of hydrolytic and oxidative enzyme methods for ecosystem studies. Appl. Soil Ecol. 43, 1387-1397.

Geyer, K.M., Kyker-Snowman, E., Grandy, A.S., Frey, S.D., 2016. Microbial carbon use efficiency: accounting for population, community, and ecosystem-scale controls over the fate of metabolized organic matter. Biogeochemistry 127, 173-188. doi:10.1007/s10533-016-0191-y

Gilliom, R.J., Barbash, J.E., Crawford, C.G., Hamilton, P.A., Martin, J.D., Nakagaki, N., Nowell, L.H., Scott, J.C., Stackelberg, P.E., Thelin, G.P., Wolock, and D.M., 2006. The Quality of Our Nation's Waters-Pesticides in the Nation's Streams and Ground Water, 1992-2001 1-184.

Gregorich, E.G., Drury, C.F., Baldock, J.A., 2001. Changes in soil carbon under longterm maize in monoculture and legume-based rotation. Can. J. Soil Sci. 81, 21-31.

Hargreaves, S.K., Hofmockel, K.S., 2013. Physiological shifts in the microbial community drive changes in enzyme activity in a perennial agroecosystem. Biogeochemistry 117. doi:10.1007/s10533-013-9893-6 Physiological

Heathcote, A.J., Filstrup, C.T., Downing, J.A., 2013. Watershed Sediment Losses to Lakes Accelerating Despite Agricultural Soil Conservation Efforts. PLoS One 8, e53554.

Hermle, S., Anken, T., Leifeld, J., Weisskopf, P., 2008. The effect of the tillage system on soil organic carbon content under moist, cold-temperate conditions. Soil Tillage Res. 98, 94-105.

Hofmockel, K.S., Fierer, N., Colman, B.P., Jackson, R.B., 2010. Amino acid abundance and proteolytic potential in North American soils. Oecologia 163, 1069-1078.

Hogh-Jensen, H., Schoerring, J.K., 2001. Rhizodeposition of nitrogen by red clover, white clover and ryegrass leys. Soil Biol. Biochem. 33, 439-448.

Hood-Nowotny, R., Umana, N.H.-N., Inselbacher, E., Oswald- Lachouani, P., Wanek, W., 2010. Alternative Methods for Measuring Inorganic, Organic, and Total Dissolved Nitrogen in Soil. Soil Sci. Soc. Am. J. 74, 1018.

Jan, M.T., Roberts, P., Tonheim, S.K., Jones, D.L., 2009. Protein breakdown represents a major bottleneck in nitrogen cycling in grassland soils. Appl. Soil Ecol. 41, 22722282.

Jenkinson, D.S., Rayner, J.H., 1977. The turnover of soil organic matter in some of the Rothamsted classical experiments. Soil Sci. 123, 298-305.

Johnson, J.M.F., Barbour, N.W., Weyers, S.L., 2007. Chemical Composition of Crop Biomass Impacts Its Decomposition. Soil Sci. Soc. Am. J. 71, 155.

Kallenbach, C., Grandy, A.S., 2011. Controls over soil microbial biomass responses to carbon amendments in agricultural systems: A meta-analysis. Agric. Ecosyst. Environ. 144, 241-252.

Kallenbach, C.M., Grandy, A.S., Frey, S.D., Diefendorf, A.F., 2015. Microbial physiology and necromass regulate agricultural soil carbon accumulation. Soil Biol. Biochem. 91, 279-290. 
Karlen, D.L., Cambardella, C.A., Kovar, J.L., Colvin, T.S., 2013. Soil quality response to long-term tillage and crop rotation practices. Soil Tillage Res. 133, 54-64.

Klopatek, J.M., Olson, R.J., Emerson, C.J., Joness, J.L., 1979. Land-use conflicts with natural vegetation in the United States. Environ. Conserv. 6, 191-200.

Kong, A.Y.Y., Six, J., Bryant, D.C., Denison, R.F., van Kessel, C., 2005. The Relationship between Carbon Input, Aggregation, and Soil Organic Carbon Stabilization in Sustainable Cropping Systems. Soil Sci. Soc. Am. J. 69, 1078-1085.

Lagomarsino, A., Moscatelli, M.C., Di Tizio, A., Mancinelli, R., Grego, S., Marinari, S., 2009. Soil biochemical indicators as a tool to assess the short-term impact of agricultural management on changes in organic $\mathrm{C}$ in a Mediterranean environment. Ecol. Indic. 9, 518-527.

Lazicki, P.A., 2011. Effect of rotation, organic inputs and tillage on crop performance and soil quality in conventional and low-input rotations in Central Iowa. MS Thesis, Urbana-Champaign.

Lazicki, P.A., Liebman, M., Wander, M.M., 2016. Root Parameters Show How Management Alters Resource Distribution and Soil Quality in Conventional and Low-Input Cropping Systems in Central Iowa. PLoS One 11, e0164209. doi:10.1371/journal.pone.0164209

Liebig, M.A., Varvel, G.E., Doran, J.W., Wienhold, B.J., 2002. Crop sequence and nitrogen fertilization effects on soil properties in the Western Corn Belt. Soil Sci. Soc. Am. J. 66, 596-601.

Liebman, M., Gibson, L.R., Sundberg, D.N., Heggenstaller, A.H., Westerman, P.R., Chase, C.A., Hartzler, R.G., Menalled, F.D., Davis, A.S., Dixon, P.M., 2008. Agronomic and Economic Performance Characteristics of Conventional and LowExternal-Input Cropping Systems in the Central Corn Belt. Agron. J. 100, 600-610.

Lipson, D.A., Schimdt, S.K., Monson, R.K., 1999. Links between microbial population dynamics and nitrogen availability in an alpine ecosystem. Ecology 80, 1623-1631.

Luo, Z., Wang, E., Sun, O.J., 2010. Can no-tillage stimulate carbon sequestration in agricultural soils? A meta-analysis of paired experiments. Agric. Ecosyst. Environ. 139, 224-231.

Madejon, E., Moreno, F., Murillo, J.M., Pelegrin, F., 2007. Soil biochemical response to long-term conservation tillage under semi-arid Mediterranean conditions. Soil Tillage Res. 94, 346-352.

Maillard, É., Angers, D.A., 2014. Animal manure application and soil organic carbon stocks: A meta-analysis. Glob. Chang. Biol. 20, 666-679. doi:10.1111/gcb.12438

McDaniel, M.D., Tiemann, L.K., Grandy, A.S., 2014. Does agricultural crop diversity enhance soil microbial biomass and organic matter dyanmics? A meta-analysis. Ecol. Appl. 24, 560-570.

McIsaac, G.F., David, M.B., Gertner, G.Z., Goolsby, D.A., 2001. Nitrate flux in the Mississippi River. Nature 414, 166-167.

Melero, S., López-Garrido, R., Murillo, J.M., Moreno, F., 2009. Conservation tillage: Short- and long-term effects on soil carbon fractions and enzymatic activities under Mediterranean conditions. Soil Tillage Res. 104, 292-298.

Moreno, F., Murillo, J.M., Pelegrin, F., Girón, I.F., 2006. Long-term impact of conservation tillage on stratification ratio of soil organic carbon and loss of total and active CaCO3. Soil Tillage Res. 85, 86-93. 
Osterholz, W.R., Rinot, O., Liebman, M., Castellano, M.J., 2016. Can mineralization of soil organic nitrogen meet maize nitrogen demand? Plant Soil 1. doi:10.1007/s11104-016-3137-1

Pandey, D., Agrawal, M., Bohra, J.S., 2014. Effects of conventional tillage and no tillage permutations on extracellular soil enzyme activities and microbial biomass under rice cultivation. Soil Tillage Res. 136, 51-60.

Poeplau, C., Don, A., 2015. Carbon sequestration in agricultural soils via cultivation of cover crops: A meta-analysis. Agric. Ecosyst. Environ. 200, 33-41.

Raab, T.K., Lipson, D.A., Monson, R.K., 1999. Soil amino acid utilization among species of the cyperaceae: plant and soil processes. Ecology 80, 2408-2419.

Randall, G.W., Huggins, D.R., Russelle, M.P., Fuchs, D.J., Nelson, W.W., Anderson, J.L., 1997. Nitrate Losses through Subsurface Tile Drainage in Conservation Reserve Program, Alfalfa, and Row Crop Systems. J. Environ. Qual. 26, 1240-1247.

Rasmussen, P.E., Allmaras, R.R., Rohde, C.R., Roager N C, J., 1980. Crop residue influence on soil carbon and nitrogen in a wheat-fallow system. Soil Sci. Soc. Am. J. 44, 596-600.

Sanford, G.R., Posner, J.L., Jackson, R.D., Kucharik, C.J., Hedtcke, J.L., Lin, T.-L., 2012. Soil carbon lost from Mollisols of the North Central U.S.A. with 20 years of agricultural best management practices. Agric. Ecosyst. Environ. 162, 68-76.

SARE, 2012. Managing Cover Crops Profitably.

Schimel, J.P., Bennett, J., 2004. Nitrogen mineralization: challenges of a changing paradigm. Ecology 85, 591-602.

Schimel, J.P., Schaeffer, S.M., 2012. Microbial control over carbon cycling in soil. Front. Microbiol. 3, 1-11.

Schmidt, M.W.I., Torn, M.S., Abiven, S., Dittmar, T., Guggenberger, G., Janssens, I.A., Kleber, M., Kögel-Knabner, I., Lehmann, J., Manning, D.A.C., Nannipieri, P., Rasse, D.P., Weiner, S., Trumbore, S.E., 2011. Persistence of soil organic matter as an ecosystem property. Nature 478, 49-56.

Schulten, H.-R., Schnitzer, M., 1998. The chemistry of soil organic nitrogen: a review. Biol. Fertil. Soils 26, 1-15.

Serna-Chavez, H.M., Fierer, N., van Bodegom, P.M., 2013. Global drivers and patterns of microbial abundance in soil. Glob. Ecol. Biogeogr. 22, 1162-1172.

Simpson, A.J., Simpson, M.J., Smith, E., Kelleher, B.P., 2007. Microbially Derived Inputs to Soil Organic Matter: Are Current Estimates Too Low? Environ. Sci. Technol. 41, 8070-8076.

Skujins, J., 1967. Enzymes in soil BT - Soil biochemistry, in: McLaren, A.D., Peterson, G.H. (Eds.), Soil Biochemistry. Marcel Dekker, New York, pp. 371-414.

Sowden, F.J., Chen, Y., Schnitzer, M., 1977. The nitrogen distribution of soils formed under widely differing climatic conditions. Geochim. Cosmochim. Acta 41, 15241526.

Syswerda, S.P., Basso, B., Hamilton, S.K., Tausig, J.B., Robertson, G.P., 2012. Longterm nitrate loss along an agricultural intensity gradient in the Upper Midwest USA. Agric. Ecosyst. Environ. 149, 10-19.

Tonitto, C., David, M.B., Drinkwater, L.E., 2006. Replacing bare fallows with cover crops in fertilizer-intensive cropping systems: A meta-analysis of crop yield and $\mathrm{N}$ dynamics. Agric. Ecosyst. Environ. 112, 58-72. 
Treseder, K.K., 2008. Nitrogen additions and microbial biomass: a meta-analysis of ecosystem studies. Ecol. Lett. 11, 1111-1120.

Vache, K.B., Eilers, J.M., Santelmann, M. V, 2002. Water quality monitoring of alternative agricultural scenarios in the U.S. Corn Belt. JAWRA J. Am. Water Resour. Assoc. 38, 773-787.

Vance, E.D., Brookes, P.C., Jenkinson, D.S., 1987. An extraction method for measuring soil microbial biomass C. Soil Biol. Biochem. 19, 703-707.

Vitosh, M.L., Lucas, R.E., Silva, G.H., 1996. Long-term effects of fertilizer and manure on corn yield, soil carbon, and other soil chemical properties in Michigan BT - Soil Organic Matter in Temperate Agroecosystems: Long Term Experiments in North America, in: Paul, E.A., Paustian, K.H., Elliot, E.T., Cole, C.V. (Eds.), Soil Organic Matter in Temperate Agroecosystems: Long Term Experiments in North America. CRC Press.

Wander, M.M., Traina, S.J., Stinner, B.R., Peters, S.E., 1994. Organic and conventional management effects on biologically active soil organic matter pools. Soil Sci. Soc. Am. J. 58, 1130-1139.

Wang, Y., Boelter, M., Chang, Q., Duttmann, R., Marx, K., Petersen, J.F., Wang, Z., 2015. Functional dependencies of soil CO2 emissions on soil biological properties in northern German agricultural soils derived from a glacial till. Acta Agric. Scand. Sect. B-Soil Plant Sci. 65, 233-245. doi:10.1080/09064710.2014.1000369

West, T.O., Post, W.M., 2002. Soil Organic Carbon Sequestration Rates by Tillage and Crop Rotation: A Global Data Analysis. Soil Sci. Soc. Am. J. 66, 1930-1946.

Witt, C., Gaunt, J.L., Galicia, C.C., Ottow, J.C.G., Neue, H.-U., 2000. A rapid chloroform-fumigation method for measuring soil microbial biomass carbon and nitrogen in flooded rice soils. Biol. Fertil. Soils 30, 510-519.

Zaimes, G.N., Schultz, R.C., Isenhart, T.M., 2008. Stream bank erosion adjacent to riparian forest buffers, row-crop fields, and continuously-grazed pastures along Bear Creek in central Iowa. J. Soil Water Conserv. 59, 19-27.

Zak, D.R., Holmes, W.E., MacDonald, N.W., Pregitzer, K.S., 1999. Soil Temperature, Matric Potential, and the Kinetics of Microbial Respiration and Nitrogen Mineralization. Soil Sci. Soc. Am. J. 63, 575-584.

Zhao, X., Xue, J.-F., Zhang, X.-Q., Kong, F.-L., Chen, J., Lal, R., Zhang, H.-L., 2015. Stratification and Storage of Soil Organic Carbon and Nitrogen as Affected by Tillage Practices in the North China Plain. PLoS One 1-15. 
A) $\quad$ C)

Native Protease

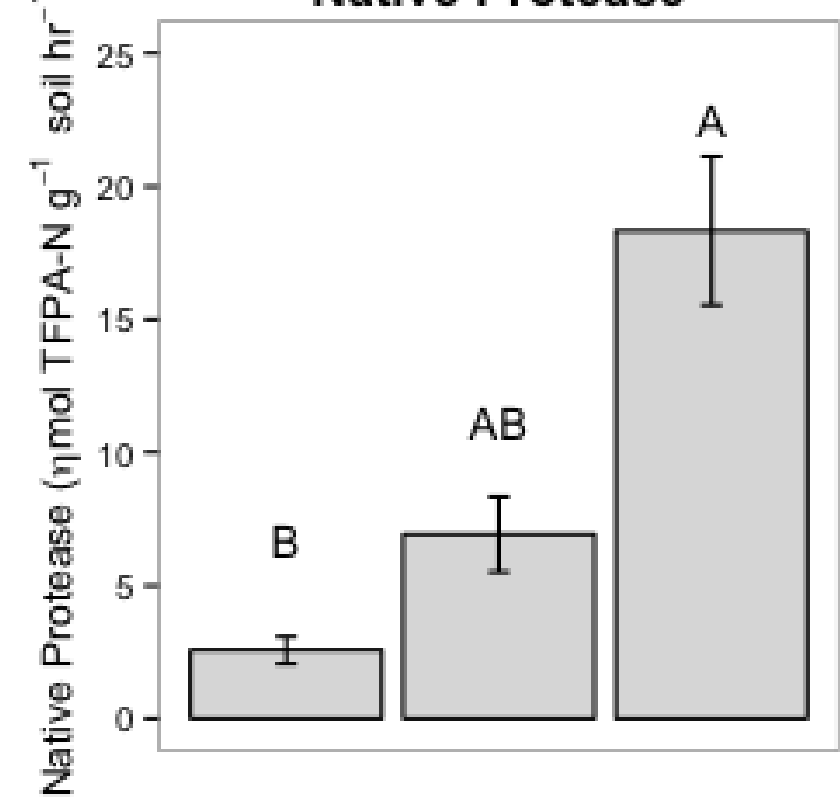

B)

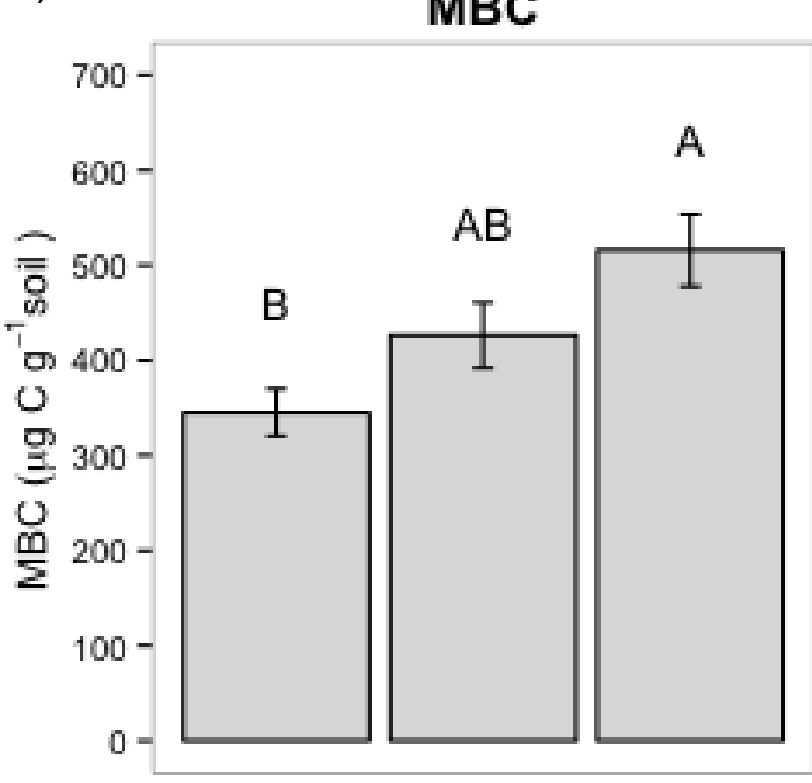

MBN

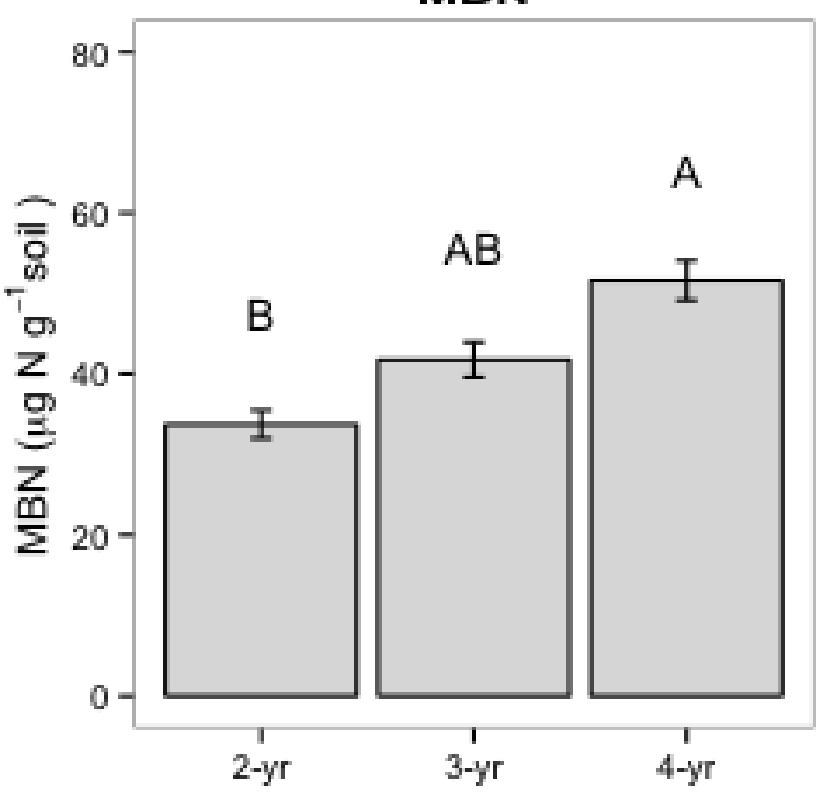

LAP

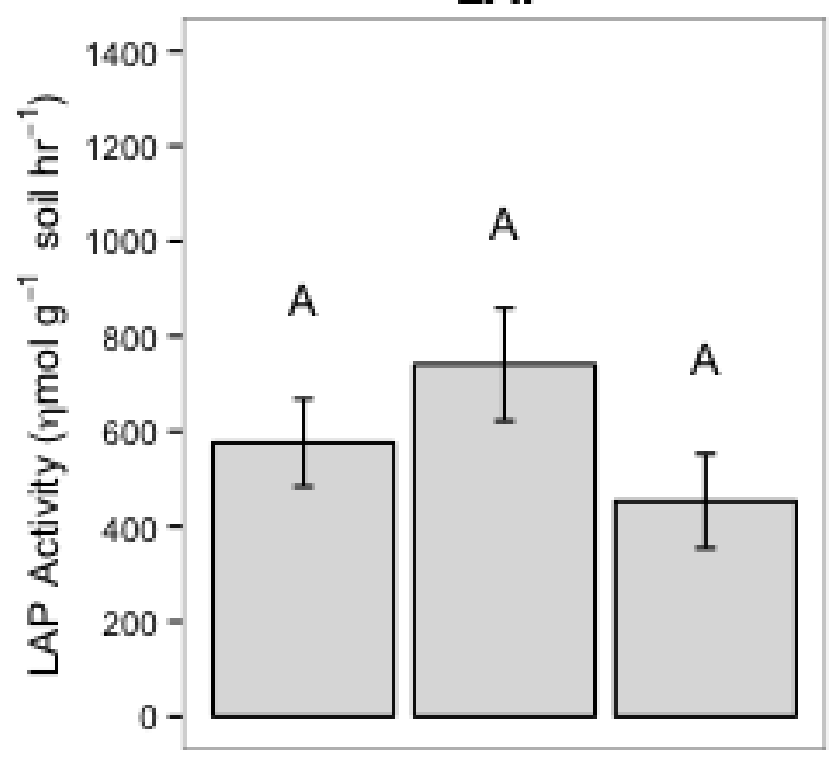

Ala

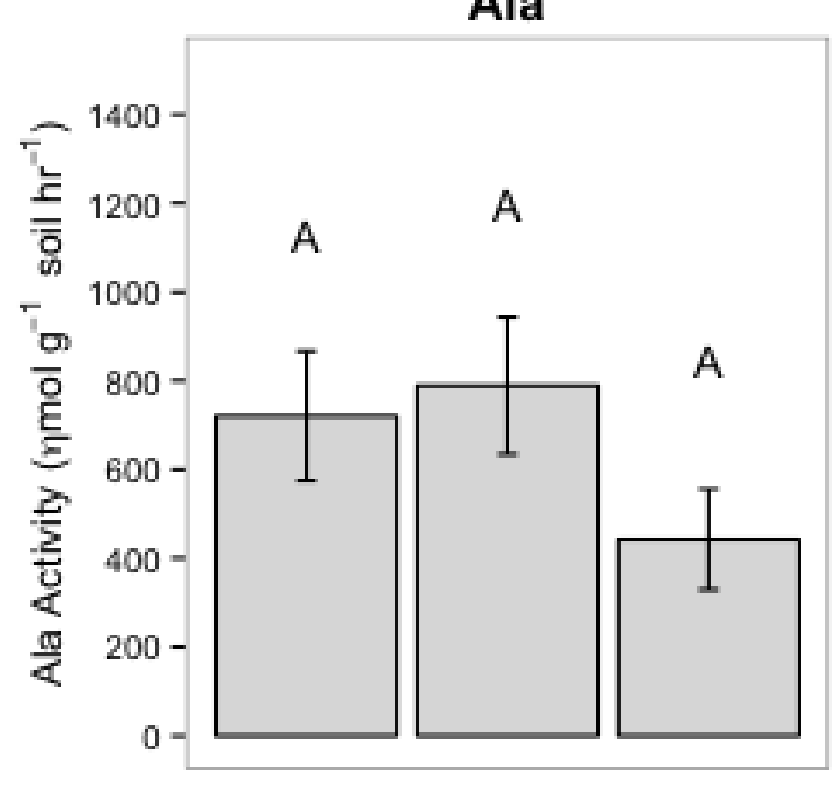

AAP

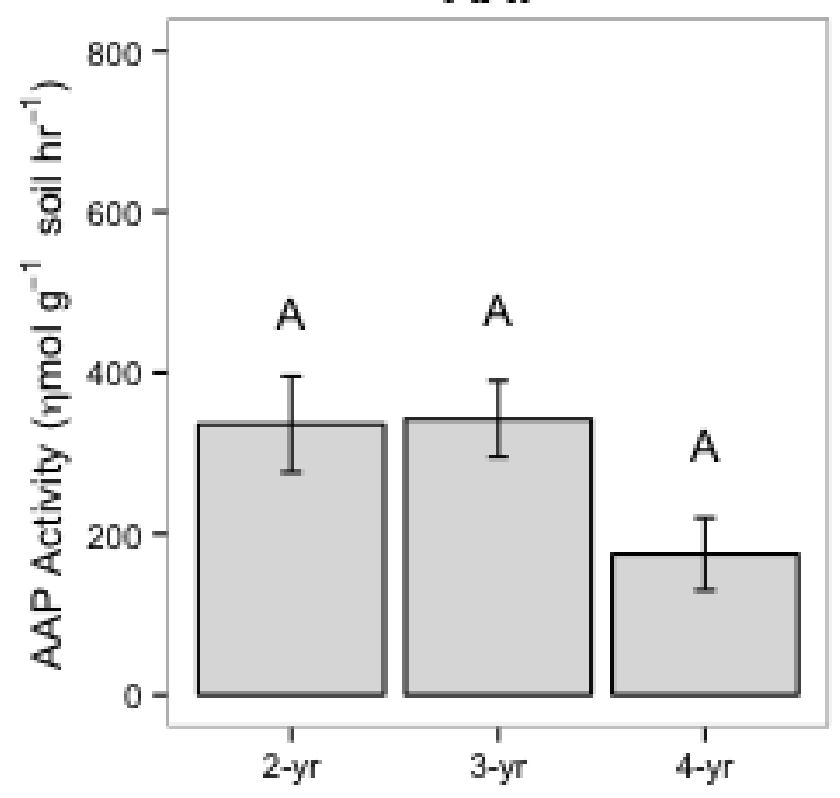

BG

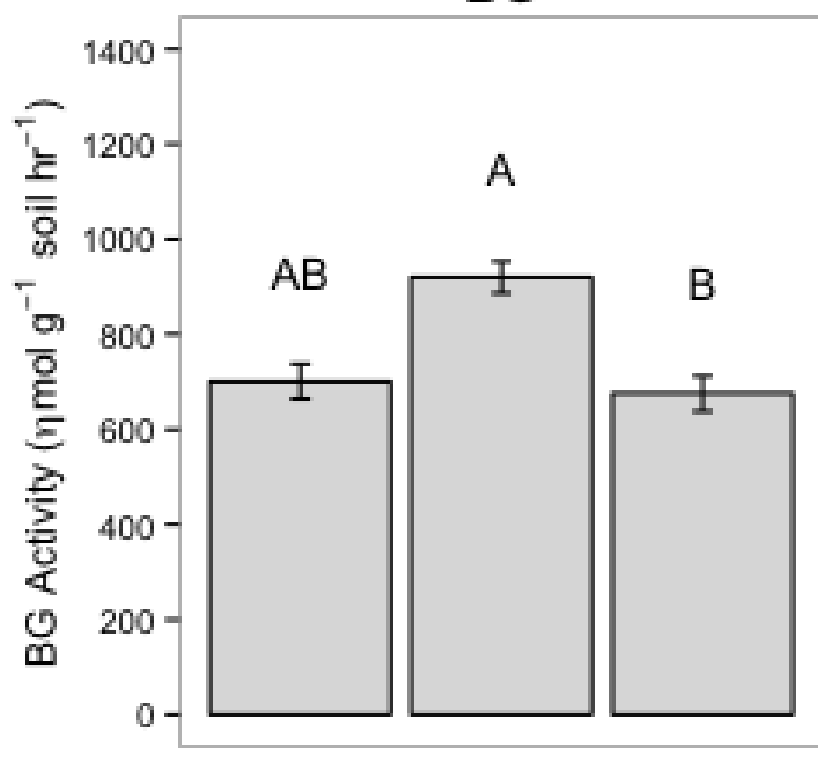

BX

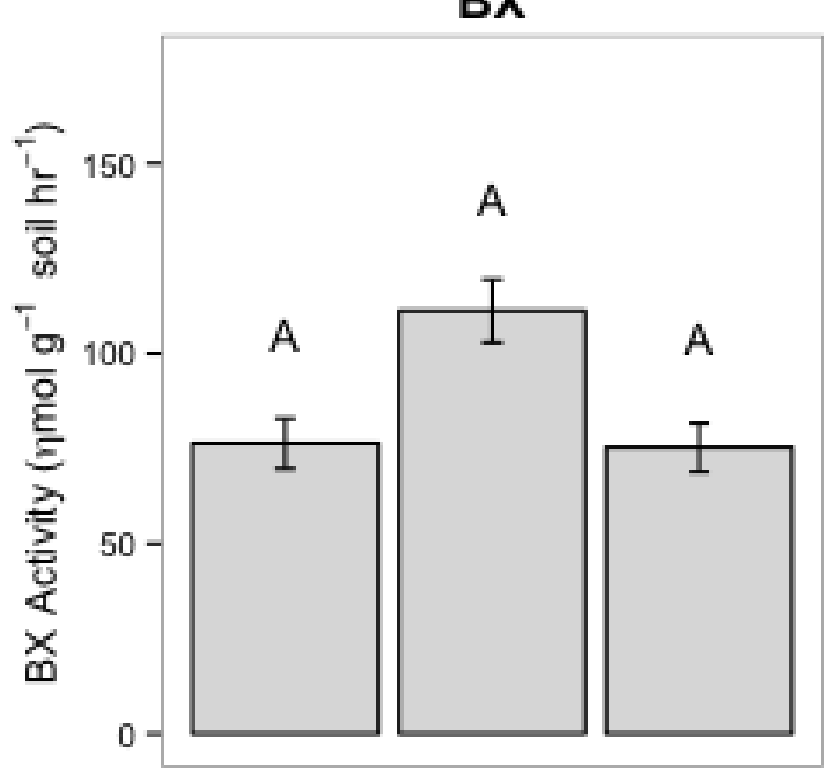

CB

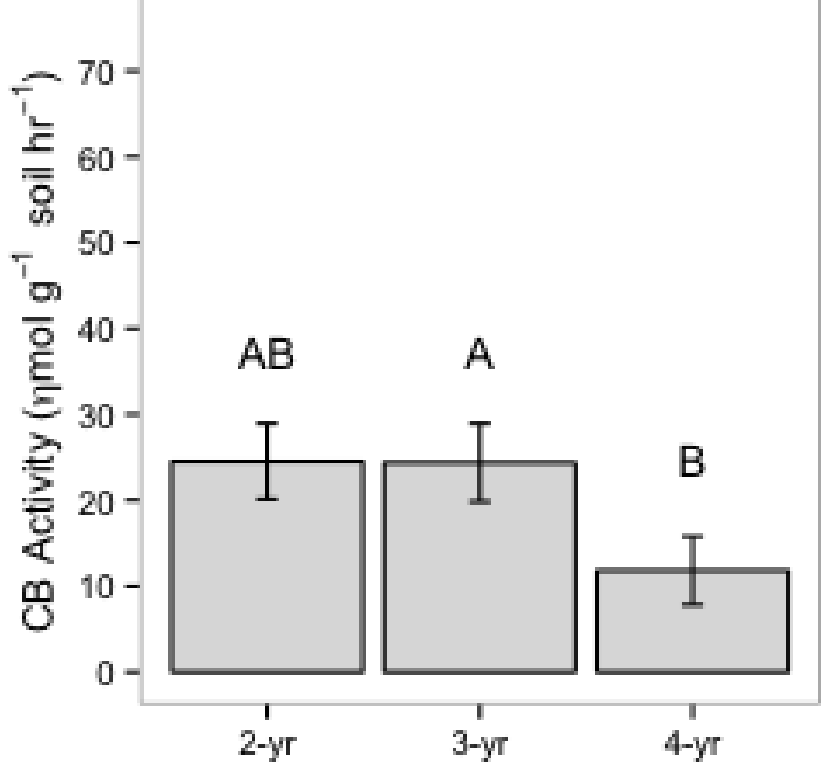


A) $\quad$ C)

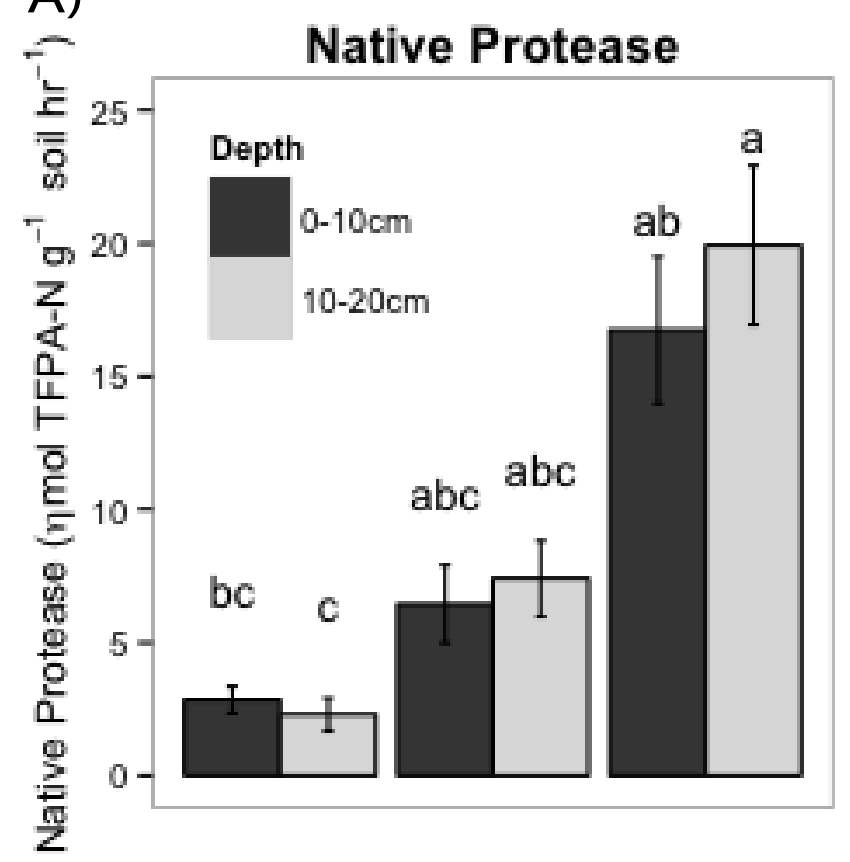

B)

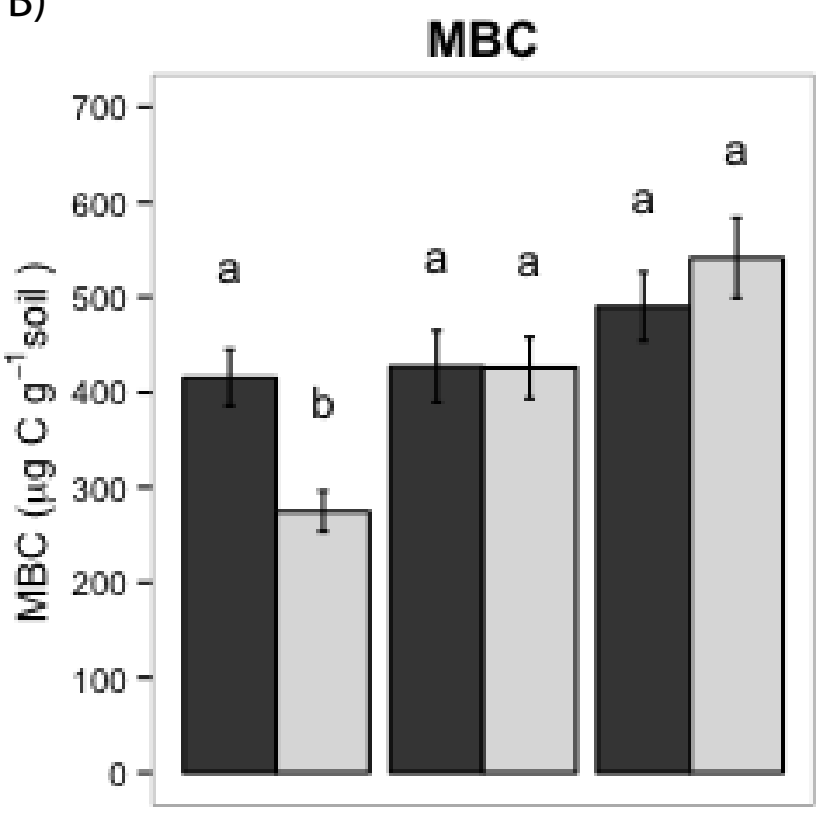

MBN

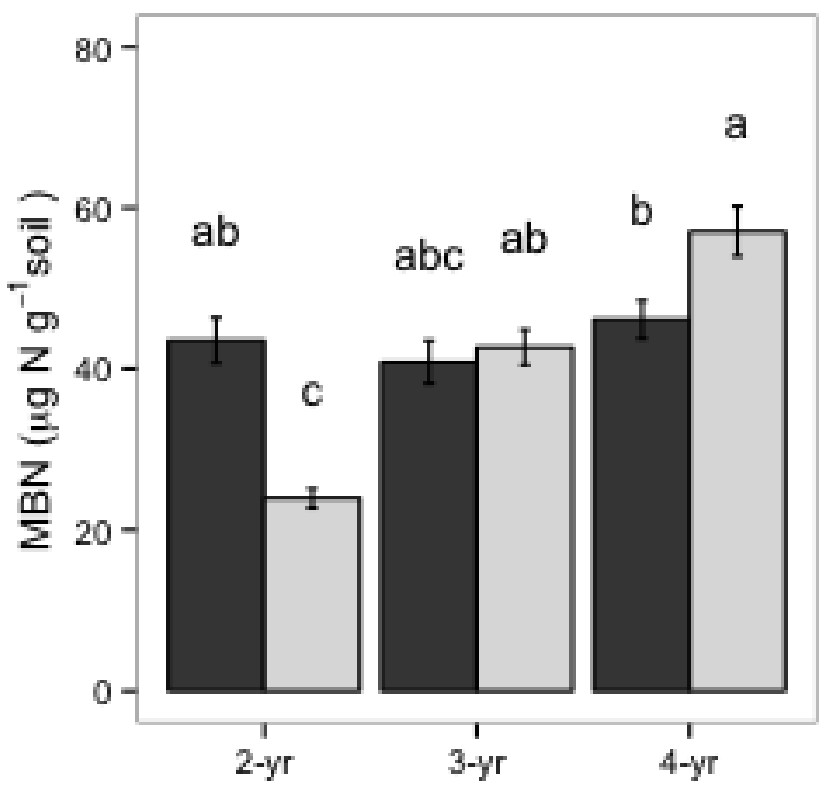

LAP

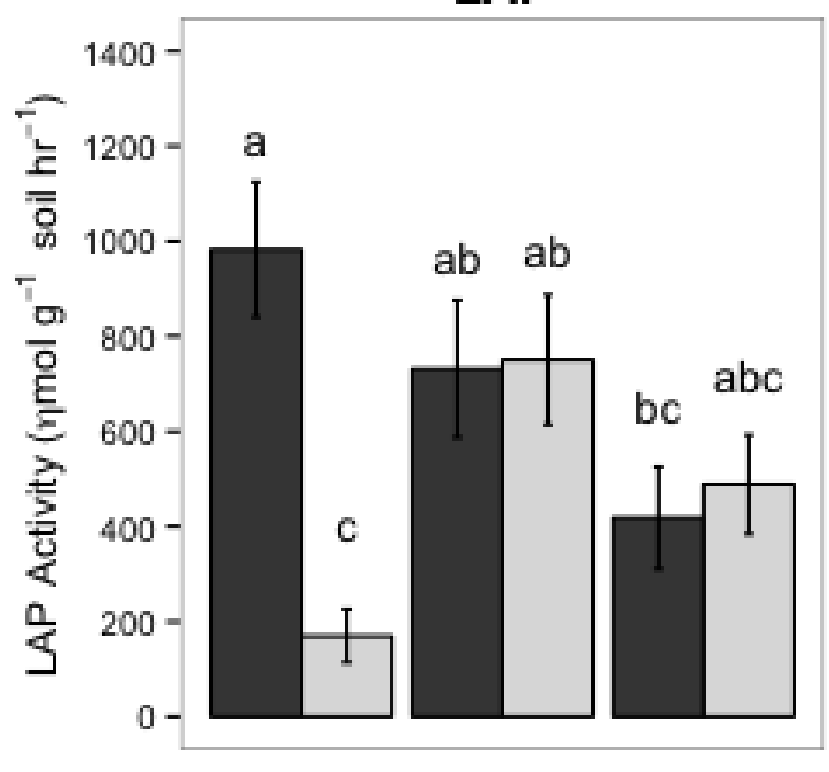

Ala

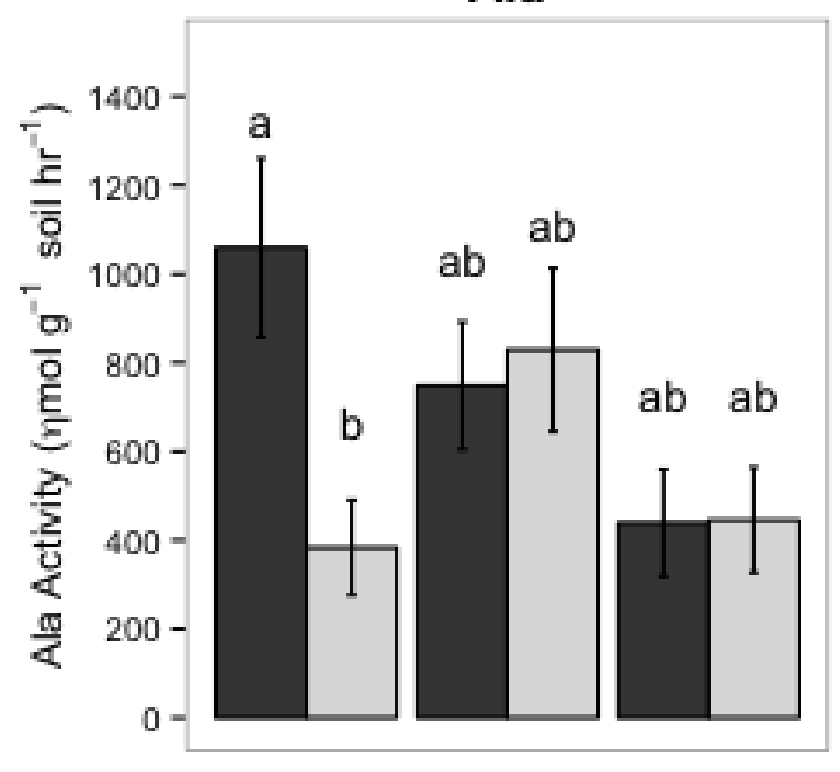

AAP

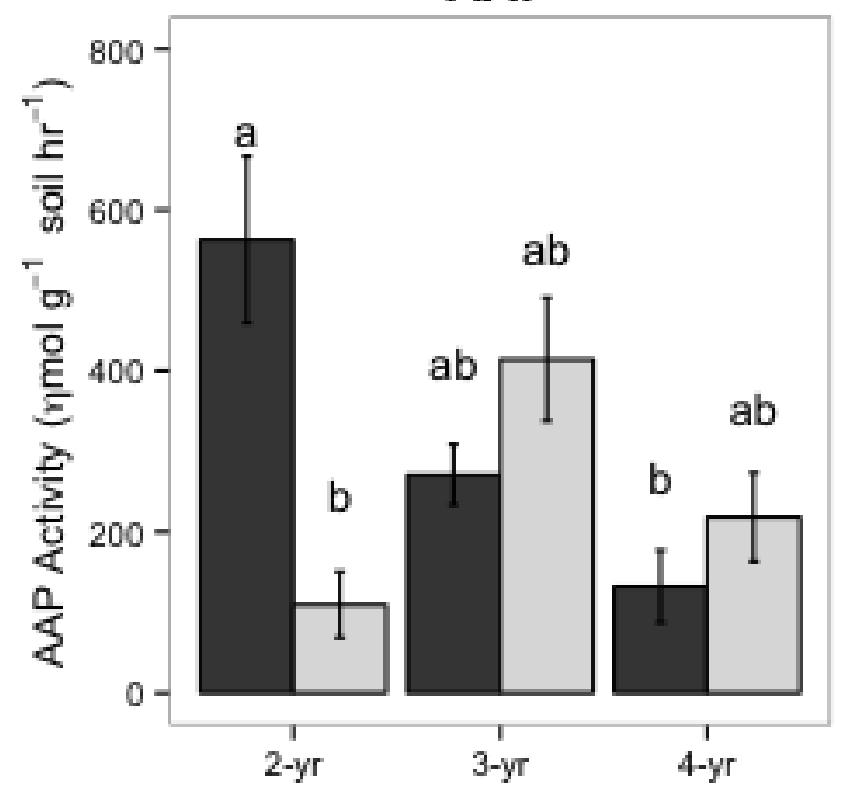

BG

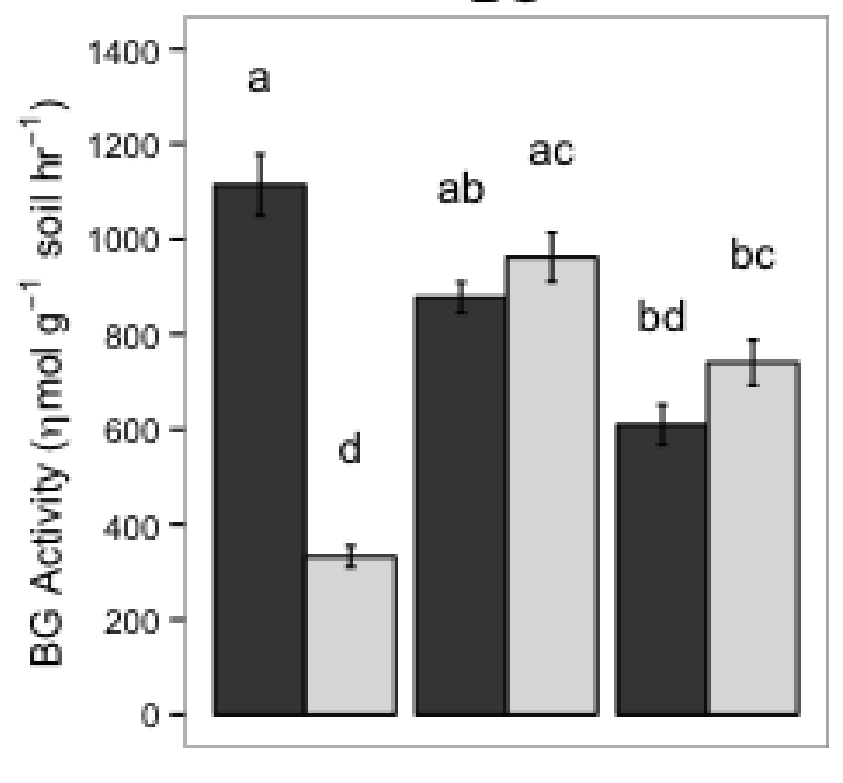

BX

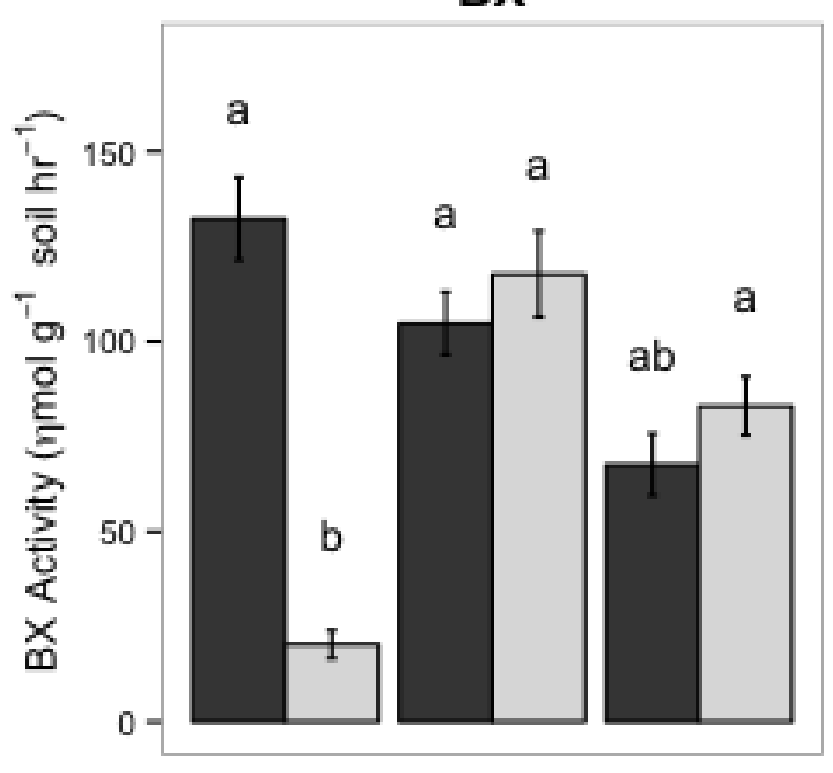

CB

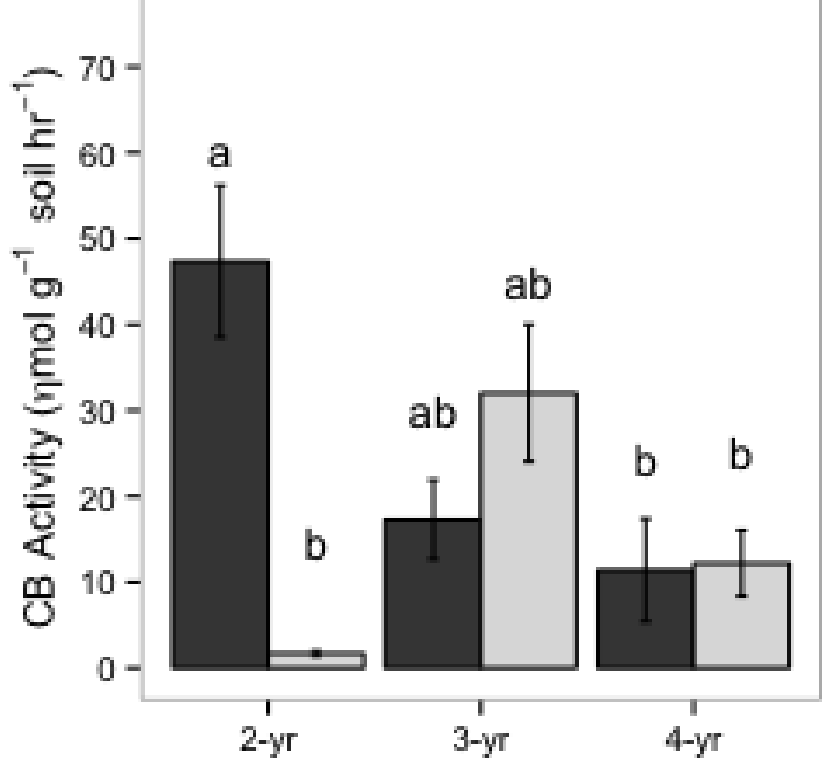


Specific LAP Activity

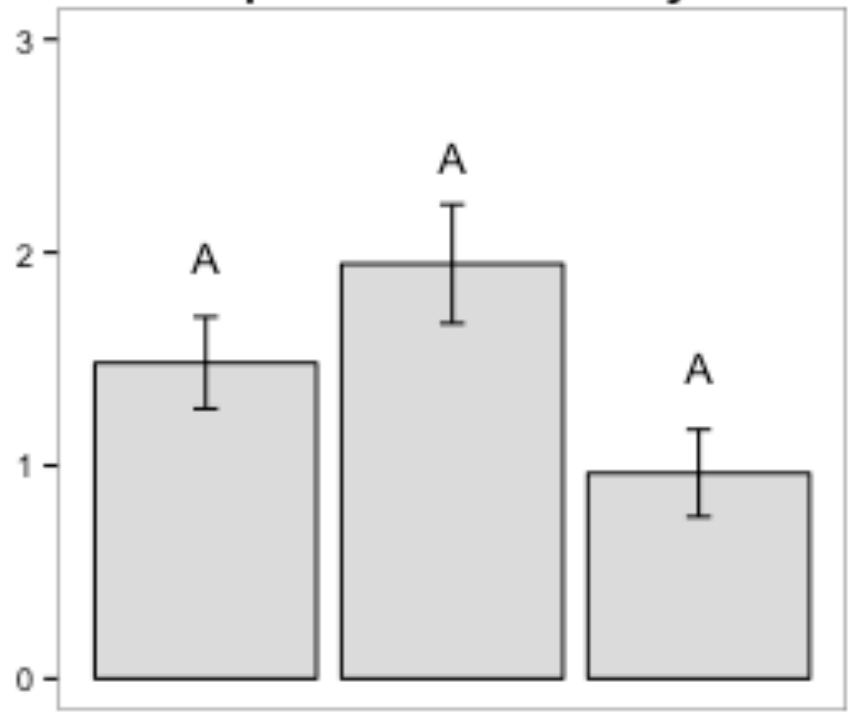

Specific Ala Activity

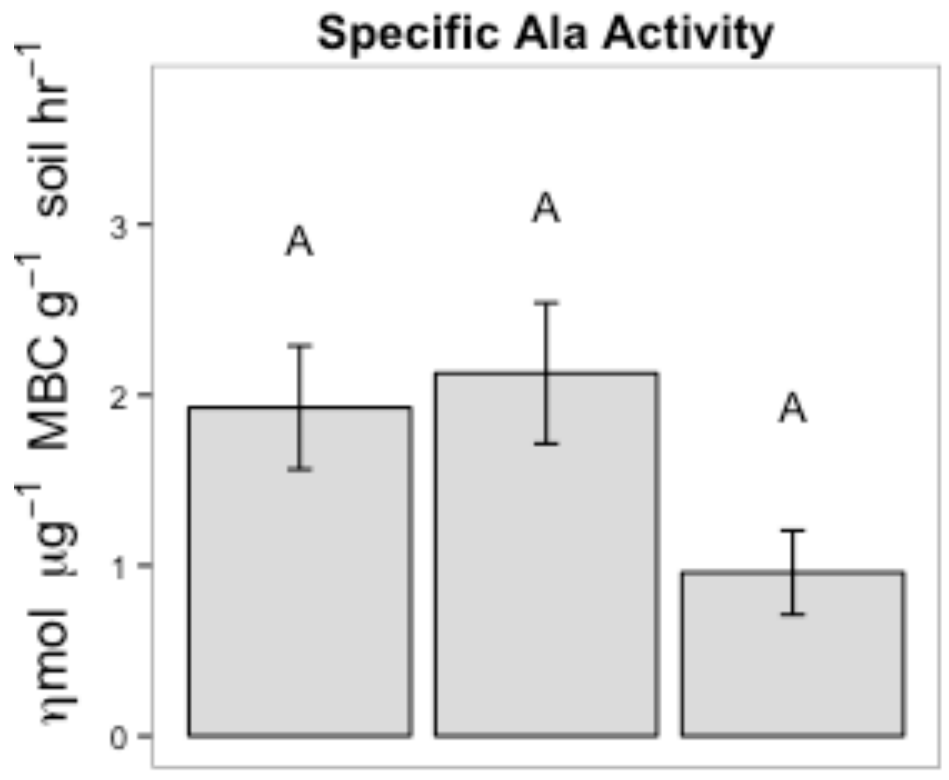

Specific AAP Activity

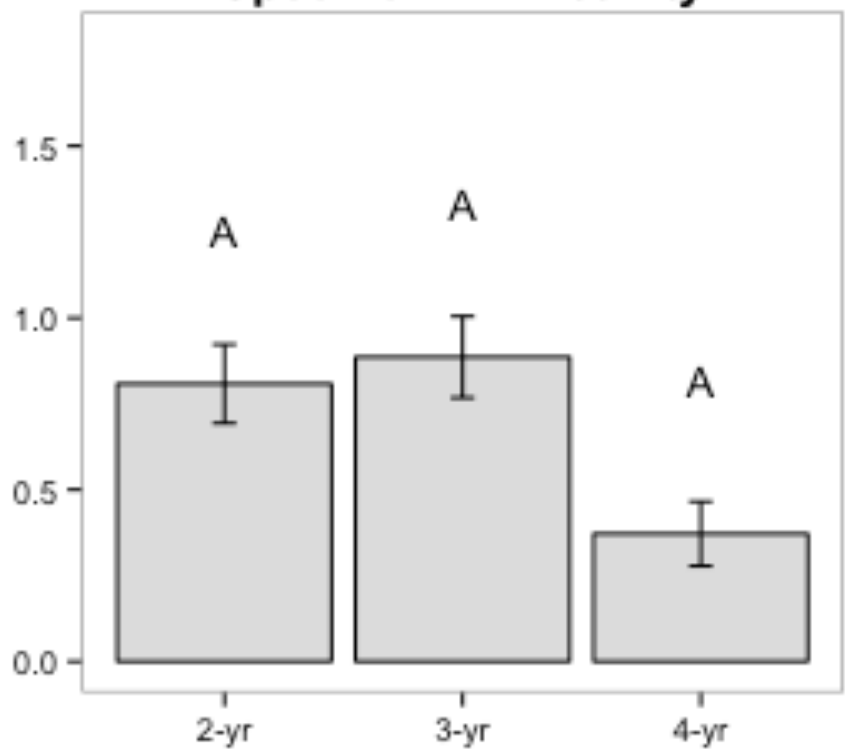

Specific BG Activity

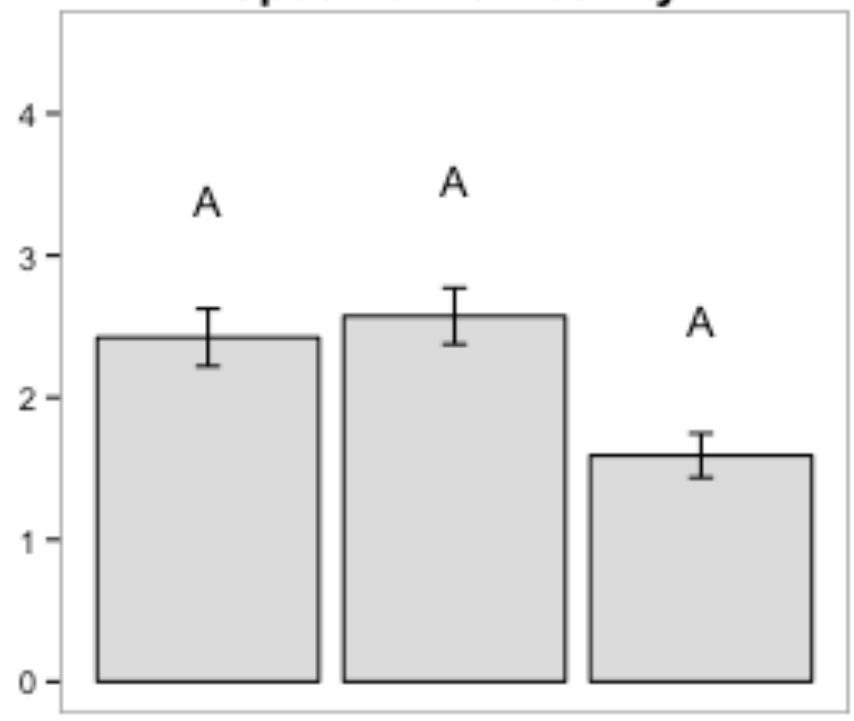

Specific BX Activity

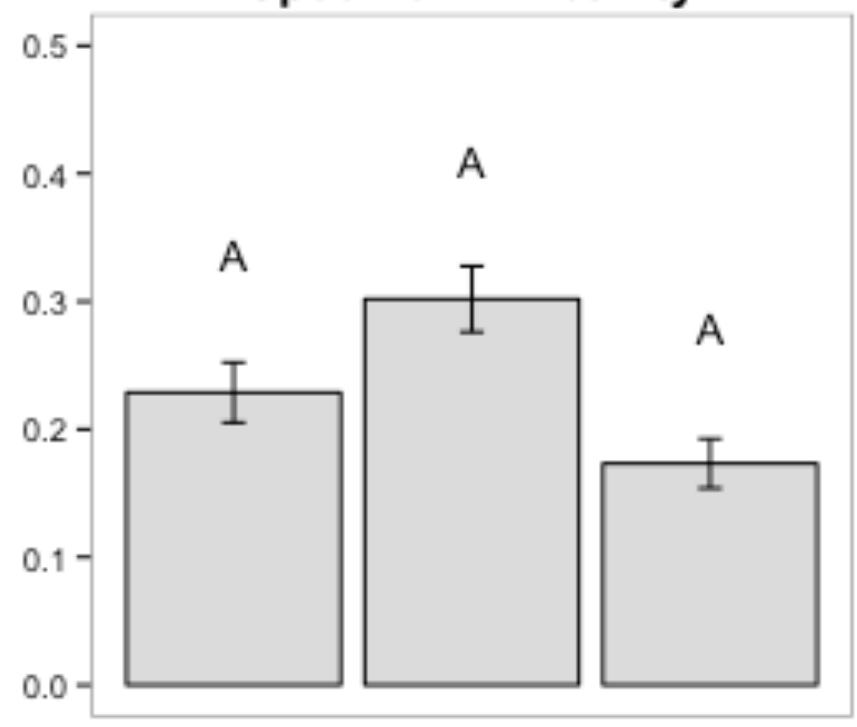

Specific CB Activity

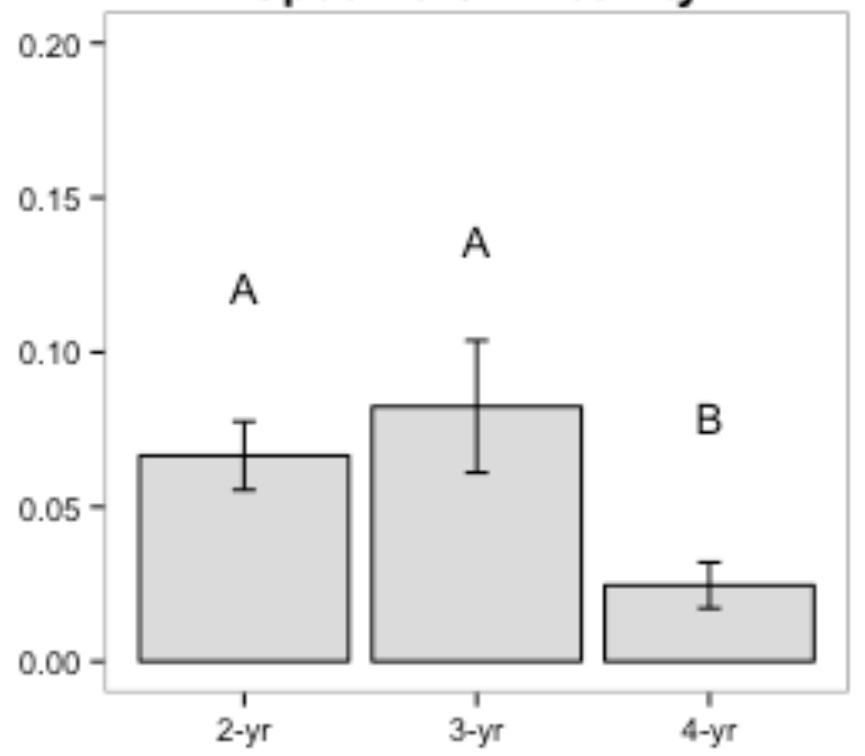



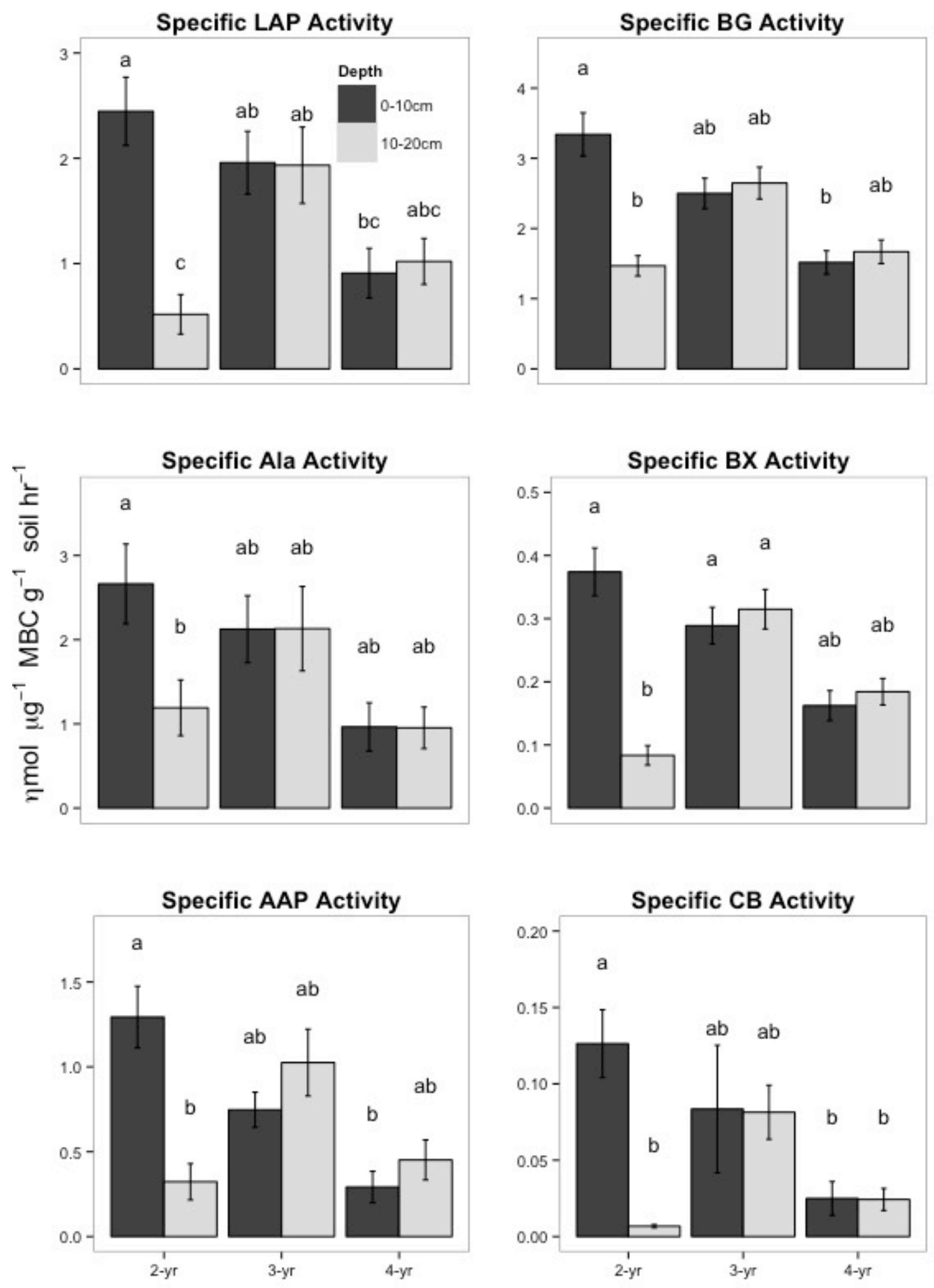


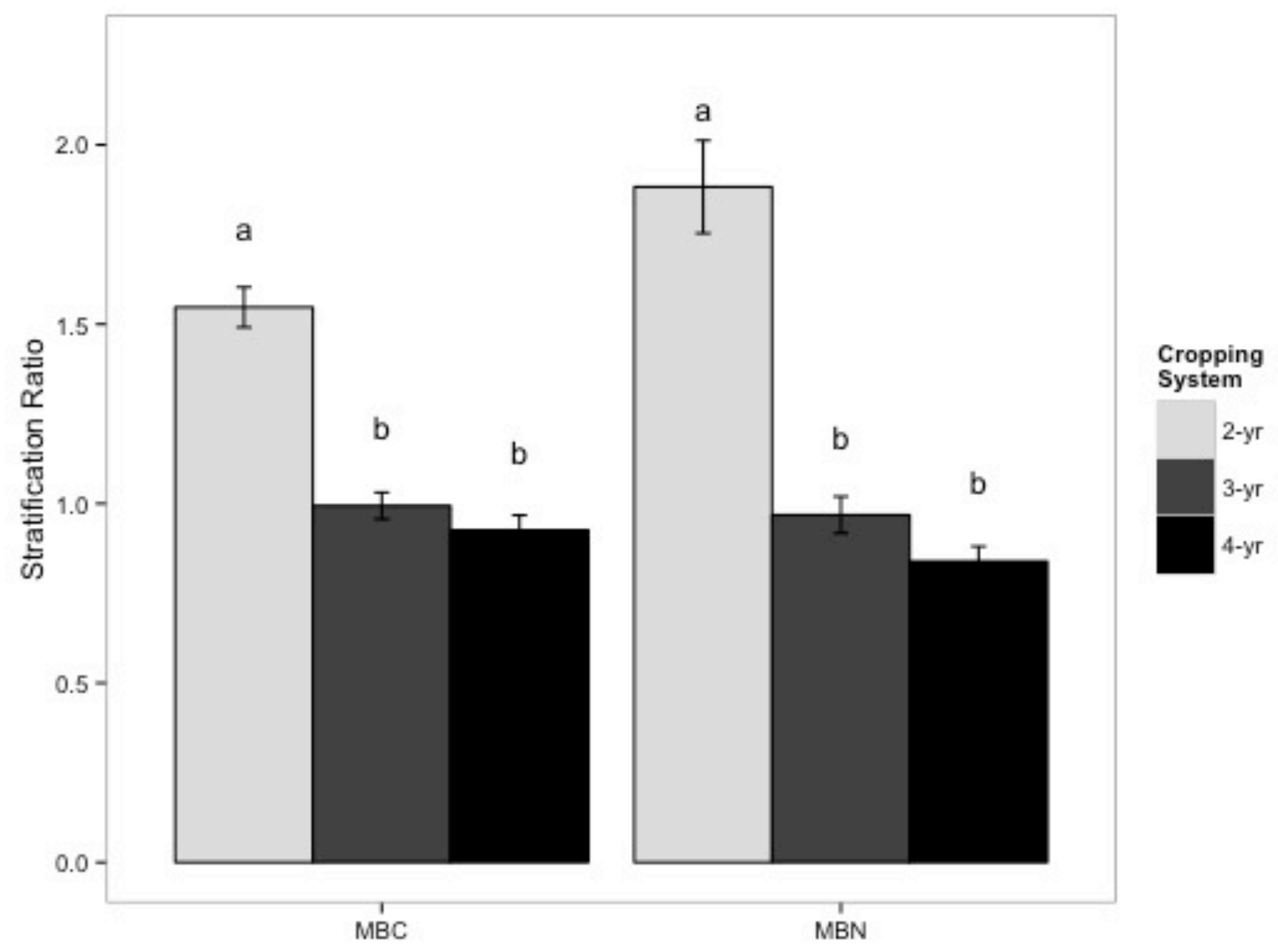




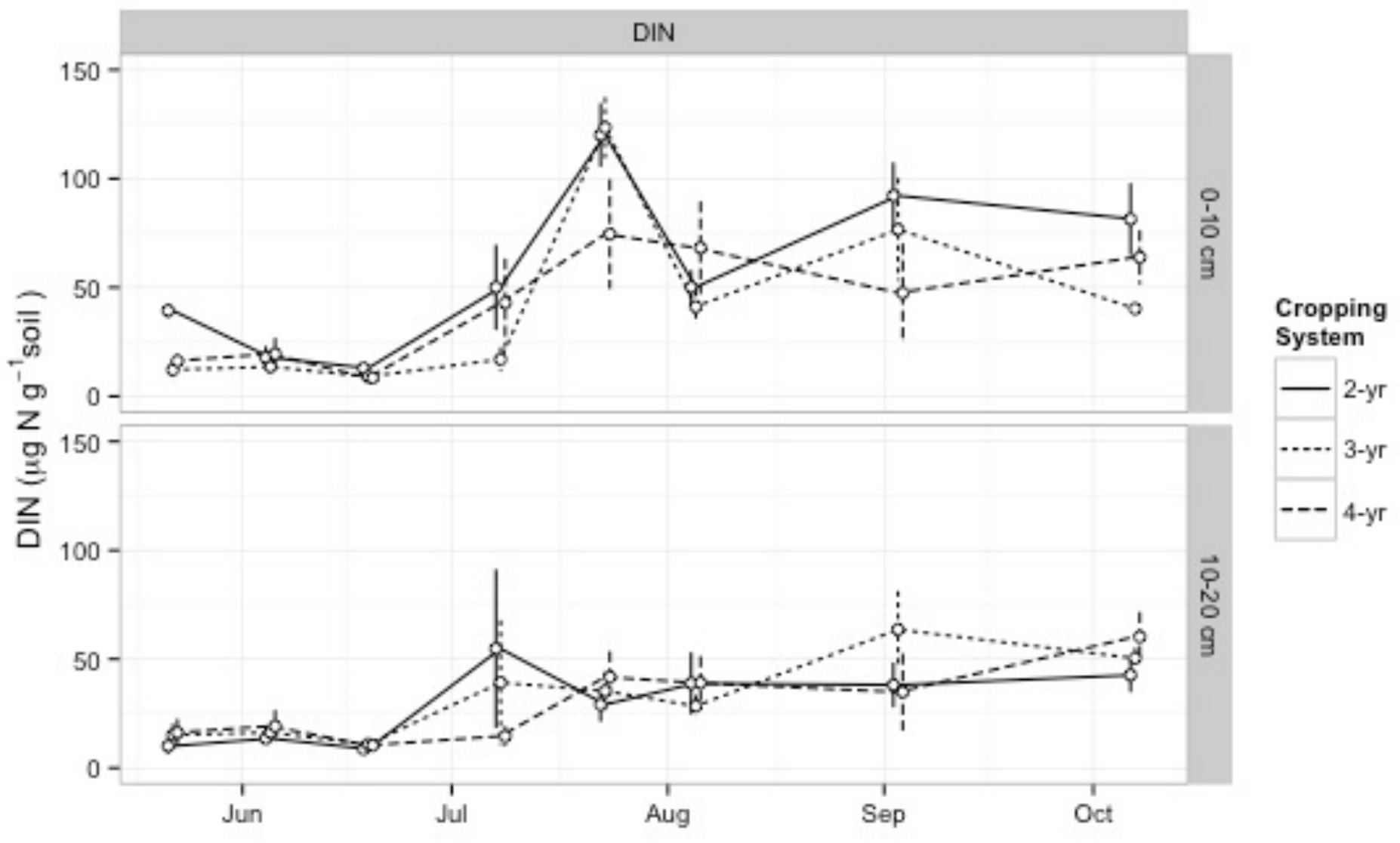

